\title{
Poor Recruitment is Changing the Structure and Species Composition of an Old-Growth Hemlock-Hardwood Forest
}

\author{
A Thesis \\ SUBMITTED TO THE FACULTY OF \\ UNIVERSITY OF MINNESOTA \\ BY
}

Theodore Thomas Salk

\section{IN PARTIAL FULFILLMENT OF THE REQUIREMENTS FOR THE DEGREE OF MASTER OF SCIENCE}

Lee Frelich, Rebecca Montgomery

July 2013 


\section{(c) (1) (2)}

This work is licensed under a Creative Commons Attribution-NonCommercial$\underline{\text { ShareAlike 3.0 Unported License }}$ 


\section{Acknowledgements}

Innumerable people have helped me with this project. My advisors, Lee Frelich and Rebecca Montgomery, and my former advisor, Shinya Sugita, have provided endless support, advice, insights, and corrections. My final committee member, Ed Cushing, has been generous with advice and impeccable copy editing. I have had the benefit of many great biology teachers in my past, including Mark McKone, Phil Camill, and Fred Holtzclaw.

The research behind this project would not have been possible without the assistance of many people. My field crew, Mike Billmire, Luke Gilner, and Andrew Thrall got done in one summer what my advisors thought would take at least two. The primary plots were originally created by Margaret Davis, who also gave wise advice and suggested the question that became the chapter on tree coring. My study would not have been possible without the high quality of the data collected by previous plot workers,

including J. Ferrari, C. Douglas, K. Walker, S. Hotchkiss, and especially Randy Calcote, who helped answer many questions about previous work in the plots. Paul Nelson singlehandedly coded the models in the first chapter in one afternoon. Tom Church and Bob Evans, with their deep love for Sylvania Wilderness, provided essential local assistance for this project. Cindy Buschena was always ready to help with supplies. This research was supported by grants from the Mellon Foundation, the Dayton-Wilkie Fund, and by National Science Foundation Grants BSR 8615196 to M.B. Davis and J. Pastor and BSR 8916503 and DEB 9221371 M.B. Davis. 
Any list of friends whose company and comfort helped me get through these years would be incomplete, so I will simply thank them in the collective. Many thanks are also due to my family. My parents first nurtured my love of the outdoors through family vacations to national parks and sending me to summer camp, and my brother has commiserated with me throughout the more trying aspects of graduate school. Finally, I would like to thank Amanda for her nonstop love, humor, and support. Every day with you is a special day. 


\begin{abstract}
Anthropogenic factors such as elevated deer populations, invasive earthworms, or climate change may alter old-growth forests of the Upper Midwest region of the United States. We examined demographic trends of woody species across all size classes for a period of 35 years in a late-successional forest dominated by hemlock (Tsuga canadensis), sugar maple (Acer saccharum), and yellow birch (Betula alleghaniensis) in Michigan's Upper Peninsula using two sets of permanent plots. For the duration of the study period, species that were less-preferred white-tailed deer (Odocoileus virginianus) forage, especially sugar maple, comprised a much higher fraction of all seedlings and saplings compared to their fraction of overstory trees. The density of small sugar maple declined across the study period, but no other species became more abundant, creating a more open forest understory. By the most recent census, preferred species for deer browse had been nearly eliminated from the understory, and declines in unpreferred species such as sugar maple were also apparent. We found small changes in temperature $\left(<0.5-1{ }^{\circ} \mathrm{C}\right.$ rise in minimum and maximum temperatures depending on season) and precipitation ( $\pm 28 \mathrm{~mm}$ depending on season) and little evidence of invasive earthworms impacts. Our results suggest that a sustained elevated deer density is shifting the structure and composition of this oldgrowth forest. A demographic model showed that if current recruitment, growth, and mortality rates were to continue for 500 years the forest would reach a new equilibrium with virtually no hemlock or yellow birch remaining.

Tree coring, or increment boring, has been a common research tool for foresters, ecologists, and climatologists for over a century. Despite its widespread use, there has been very little research into the effect of this practice on the growth and mortality of trees. Using data from two of the permanent plots, we compared the growth and mortality rates of cored trees to a similar set of uncored trees for 16-18 years. While there might have been some slight bias in selecting trees for coring, it is unlikely to have affected our overall results. Cored trees did not differ in their mortality rate from uncored trees and had only minute differences in growth, either when considered collectively or when looking at species individually.
\end{abstract}




\section{Table of Contents}

\section{Acknowledgements}

Abstract

iii

Table of Contents

iv

List of Tables

List of Figures

vi

Chapter 1: Poor Recruitment is Changing the Structure and Species Composition of an Old-Growth Hemlock-Hardwood Forest

Chapter 2: No Observed Impact of Coring on Diameter Growth or Mortality of Trees in an Old-Growth Hemlock-Hardwood Forest

\section{References}

Appendix 


\section{List of Tables}

\section{Chapter 1.}

Table 1. The browse preference rankings of Dahlberg and Guettinger (1956) for species with more than 10 stems $>5 \mathrm{~cm}$ dbh in 2006 in the Davis plots in Sylvania Wilderness, Michigan.

\section{Chapter 2.}

Table 1. Summary table of data used in this study.

Table 2. Summary of results of effect tests for regressions.

Table 3. Annual mortality rates for cored and uncored hemlock (Tsuga canadensis), sugar maple (Acer saccharum), and yellow birch (Betula alleghaniensis), and comparison to other reported values for canopy trees in old-growth forests in Upper Michigan. 


\section{List of Figures}

\section{Chapter 1.}

Figure 1. The relative composition of the three most common tree species in the Davis plots in Sylvania Wilderness, Michigan.

Figure 2. The annual mortality rate by original size class in the Davis plots in Sylvania Wilderness, Michigan, between the first (1987-90) and third census (2006) for the three most abundant species.

Figure 3. The density of seedlings across three of the Davis plots in Sylvania Wilderness, Michigan.

Figure 4. The total number of stems in the Davis plots in Sylvania Wilderness, Michigan by species in $10 \mathrm{~cm}$ DBH size classes.

Figure 5. Measured and future predicted size distribution curves for hemlock, sugar maple, and yellow birch in the Davis Plots in Sylvania Wilderness, Michigan.

Figure 6. Photos from one of the Davis plots.

\section{Chapter 2.}

Figure 1. Schematic diagrams of experimental layout. 
Chapter 1: Poor Recruitment is Changing the Structure and Species Composition of an Old-Growth Hemlock-Hardwood Forest 


\section{Introduction}

Logging that accompanied European settlement reduced late-successional forests to a tiny fraction of the current land cover in the eastern United States (Davis 1996). Today, oldgrowth remnants are sometimes seen as models for restoring eastern forests to more historical conditions (e.g., Mladenoff et al. 1993). However, remnant forests may be changing from anthropogenic impacts besides logging, making them imperfect templates for restoration. Identifying these impacts and measuring their effect on the forest community will lead to a clearer picture of the pre-European forest and inform restoration efforts.

In northern Michigan and Wisconsin, USA, eastern hemlock (Tsuga canadensis) - hardwood forest was one of the most abundant forest types prior to European settlement, and today covers only about $0.2 \%$ of its original extent (Frelich 1995, Davis et al. 1996). Fires are rare in this forest type, and the primary form of disturbance is the treefall gap of one to a few trees (Frelich and Lorimer 1991, Parshall 1993, Frelich and Graumlich 1994). The common species of the hemlock-hardwood forest are moderately to highly shade tolerant, with abundant advanced regeneration of shade-tolerant species such as hemlock and sugar maple (Acer saccharum) and regeneration within treefall gaps of moderately tolerant species such as yellow birch (Betula alleghaniensis) and American basswood (Tilia americana). Some species, such as hemlock and yellow birch, germinate well on the tip-up mounds and coarse woody debris that are abundant in old forests (Marx and Walters 2008).

These forests also have pronounced separation into hemlock and hardwood dominated patches up to 40 ha in size due to the combined influence of neighborhood effects and environmental variation (Pastor and Broschart 1990, Frelich et al. 1993, Frelich 2002). Sedimentary pollen records indicate that the location of these patches has in many cases changed little since the arrival of hemlock to the region 3000-4000 years ago (Davis et al. 1998).

Although many remnant old-growth hemlock-hardwood stands are now protected from logging, their composition and dynamics may be changing due to anthropogenic factors such as exotic earthworm invasion and elevated deer populations, with future 
changes likely due to invasive tree pests, diseases, and climate change. There are no earthworms native to the Upper Midwest of the United States, but several species have been widely introduced. Earthworm species vary in their effect on the plant community, with the greatest impact coming from species that consume the duff layer, reducing soil nutrients and making the forest floor less hospitable for seed germination (Hale et al. 2005, Frelich et al. 2006, Holdsworth et al. 2007).

Modern white-tailed deer (Odocoileus virginianus) populations are significantly higher than historical levels in much of the eastern United States, including in the Upper Peninsula of Michigan, where Doepker et al. (1995) estimate modern populations to be around twice those from before European settlement. Studies have shown that deer herbivory changes the forest floor community, in particular decreasing the density and diversity of the forbs and tree seedlings that deer preferentially browse (Beals et al. 1960, Mudrak et al. 2009). Several studies have shown a close link between deer browsing and poor regeneration of hemlock (Anderson and Loucks 1979, Frelich and Lorimer 1985, Anderson and Katz 1993, Rooney and Waller 1998, Rooney et al. 2000). Moreover, a study in the boreal forest of Anticosti Island in Quebec, Canada found that after sustained elevated deer browsing had largely eliminated preferred species from the forest, deer consumed balsam fir (Abies balsamea) to such an extent that its composition in the canopy was declining while that of even less-preferred spruce (Picea spp.) increased (Tremblay et al. 2005). If similar processes are present in hemlock-hardwood forest, deer could disrupt the patch dynamics between sugar maple and hemlock that have been in place for the last few millennia by affecting both species negatively, but hemlock more negatively than sugar maple (Witt and Webster 2010).

In this paper we use two multi-decadal data sets and a simple forest dynamics model to (1) examine trends in the density and species composition of woody stems from seedlings to canopy trees in an old-growth hemlock-hardwood forest and (2) explore possible evidence for mechanisms behind these trends. Given anthropogenic factors, we expect that density and composition will change across our census period and that deer browse will be a major cause of this change. We do not expect to find invasive earthworms because our sites are undisturbed and relatively remote from roads, 
characteristics correlated with uninvaded forests (Holdsworth et al. 2007). Furthermore, we hypothesize that tree species less preferred by deer will have different size class distributions and higher recruitment than more preferred species. Finally, we predict that changes in forest floor composition could feed up to subcanopy and canopy trees, changing the size structure and species composition of the forest.

\section{Materials and Methods}

\section{Study Area}

Sylvania Wilderness Area is a unit of Ottawa National Forest in Michigan's Upper Peninsula $\left(46^{\circ} 13^{\prime} \mathrm{N}, 89^{\circ} 18^{\prime} \mathrm{W}\right)$. It is home to 6000 ha of contiguous unlogged late-successional hemlock-hardwood forest. Although hemlock, sugar maple and yellow birch compose the majority of the trees in the canopy, American basswood, ash (Fraxinus spp.), red maple (Acer rubrum), white pine (Pinus strobus), ironwood (Ostrya virginiana), northern white cedar (Thuja occidentalis), and a few minor species are also present. The pitted outwash terrain that dominates Sylvania is part of the Winegar Moraine (Bockheim and Jordan 2004). The primary soil is the coarse-loamy Gogebic Series, with patches of sandier soil interspersed.

The climate in Sylvania is cold continental. We used data from the PRISM Climate Group (2010) to describe climatic values for the period 1895-2008. Mean annual precipitation was $812 \mathrm{~mm}$, with $290 \mathrm{~mm}$ coming during the summer (JuneAugust). The average annual daily high temperature was $10^{\circ} \mathrm{C}$, and low temperature was $-2^{\circ} \mathrm{C}$. For June-August these values were $24^{\circ} \mathrm{C}$ and $10^{\circ} \mathrm{C}$, respectively. Linear regressions of these climate values showed an approximately $1^{\circ} \mathrm{C}$ rise in both summertime and annual minimum temperatures and a less than $0.5^{\circ} \mathrm{C}$ change in summertime and annual maximum temperatures. Average annual precipitation increased by $27 \mathrm{~mm}$, while average summertime precipitation decreased by $28 \mathrm{~mm}$.

\section{Davis Plots}

Between 1987 and 1990, members of the lab of Margaret Davis, University of Minnesota - Twin Cities, established four permanent plots (A-D) in Sylvania (Davis plots). The plots range from 5 to 10 ha in size, with a total area of 27.45 ha. These plots mainly consist of upland hemlock-hardwood forest, although there is also a small area of 
bogs, ash wetlands, and small ponds. Plot locations were originally selected to include different spatial patterns in the hemlock-hardwood forest where there were small hollows suitable for paleoecological research (Frelich et al. 1993, Davis et al. 1994).

In each plot, all woody stems at least $5 \mathrm{~cm}$ in diameter at $1.4 \mathrm{~m}$ above the ground (dbh), were mapped and tagged, and had their species recorded and dbh measured. Each plot was recensused between 1993 and 1995 and again in 2006. At each recensus, all new trees were tagged and mapped using previously mapped trees as reference points. During the second and third censuses all woody stems $>2 \mathrm{~m}$ tall, but $<5 \mathrm{~cm}$ dbh (hereafter "saplings") in the plots were mapped and placed into one of two dbh classes: $<3 \mathrm{~cm}$ or $3-$ $5 \mathrm{~cm}$.

The density of woody stems $<2 \mathrm{~m}$ tall (hereafter "seedlings") were measured in permanent $2 \times 2 \mathrm{~m}$ subplots at randomly selected locations $>20 \mathrm{~m}$ from plot boundaries. Subplot corners were marked with rebar poles. Subplots could, and often did, contain standing trees and coarse woody debris. Fifty subplots were installed in Plot A in 1990 and the total number of stems $<2 \mathrm{~m}$ tall for each woody species was counted, except for sugar maple, which was counted in three height classes: $<50 \mathrm{~cm}, 50-100 \mathrm{~cm}$, and 100$200 \mathrm{~cm}$. In 1991, 50 subplots in Plot B and 25 subplots each in plots C and D were installed and the number of stems of each species was counted in three height classes $(0-$ $50 \mathrm{~cm}, 50-100 \mathrm{~cm}$, and 100-200 cm). Percent cover below two meters in height was estimated for each species.

In 2006, we recensused all of the subplots using the same methods as the 1991 census. We were unable to find the rebar corners for four subplots, in which case their location was estimated from their mapped location.

We sampled for earthworms between 29 September and 5 October 2006 adjacent to 68 randomly selected subplots scattered across the four mapped plots. We removed the leaf litter from $0.1 \mathrm{~m}^{2}$ of ground and examined it for earthworms, after which $4 \mathrm{~L}$ of water mixed with approximately $80 \mathrm{~cm}^{3}$ of mustard powder were poured onto the bare soil, following the techniques of Holdsworth et al. (2007). All of the earthworms that emerged from the soil within 15 minutes or had been found in the leaf litter were preserved in $10 \%$ formalin for later identification. 


\section{Deer Browse Preference and Size Class Distribution}

We used the browse preference rankings of Dahlberg and Guettinger (1956) to categorize each species with at least $10 \mathrm{stems} \geq 5 \mathrm{~cm}$ dbh in our plots as preferred browse, a rank of I, II, or II-III, or unpreferred browse,- a rank of III, III-IV, or IV (Table 1). There was no ranking given for green ash (Fraxinus pennsylvanica), and since there were inconsistencies between census years in the identification of green ash versus the closely related white ash (Fraxinus americana), the two species were combined in analyses and assumed to share the deer browse ranking of white ash (III). We compared the size-class distributions of the species in the two groups using data from the third census, because the effects of deer herbivory should become increasingly apparent the longer the period of elevated deer density.

\section{Stearns and Sotala Plots}

In 1974-75, Forest Stearns and Dennis Sotala of the University of Wisconsin Milwaukee established a series of permanent plots in Sylvania, including eight sites similar to the Davis plots - late-successional, uneven-aged stands dominated by sugar maple, hemlock, yellow birch, and/or basswood. Stearns and Sotala recensused these plots in 1990, and we did so in 2009. Each site consisted of two $30 \times 6.7 \mathrm{~m}$ (0.02 ha) plots where every tree $>2.54 \mathrm{~cm}$ ( 1 inch) was measured and identified to species. Subplots for sampling stems $>0.91 \mathrm{~m}$ tall but $<2.54 \mathrm{~cm}$ dbh were situated at two corners of each plot at opposite ends of the $30 \mathrm{~m}$ axis. The subplot dimensions were $4 \times 1 \mathrm{~m}$, with the long axis of the subplot parallel to the long axis of the larger plot.

\section{Data Analysis and Demographic Model}

Because the four Davis plots had broadly similar patterns of relative composition, recruitment, growth, and mortality, we combined data from all plots in our analyses. For example, sugar maple, hemlock, and yellow birch each comprised at least $15 \%$ of all of the stems $>35 \mathrm{~cm}$ dbh in the first census in each plot. Combined, the three species accounted for $>70 \%$ of all stems $>35 \mathrm{~cm}$ dbh in each plot in the first census. Data for each plot separately can be found in Appendix A. We did not perform formal analyses of statistical significance because we had a complete census of all stems within the Davis plots. 
We created a simple model of future basal area of the three most common species, hemlock, sugar maple, and yellow birch, by projecting the measured species-specific recruitment, growth, and mortality rates from the Davis plots forward until equilibrium in the dbh-size class distribution occurred. Because there would likely be feedbacks between these rates and basal area, this model is intended as a tool to explore the power of current trends to alter the forest rather than a specific prediction of what the future forest will look like. Growth and mortality rates were calculated in $10 \mathrm{~cm}$ dbh classes starting at $5 \mathrm{~cm}$ dbh (i.e., $5-15 \mathrm{~cm}, 15-25 \mathrm{~cm}$, etc.). Because the small numbers of stems in the largest size classes reduce confidence in our estimates of growth and mortality, we combined the largest classes into a single class consisting of all stems $>75 \mathrm{~cm} \mathrm{dbh}$. Annual mortality rate, $M$, was calculated as (1) $M=1-\left(N_{t} / N_{0}\right)^{1 / t}$

where $N_{0}$ is the number of stems alive at time $=0, N_{t}$ is the number of stems from the original cohort that are still alive, whether or not they changed size class, and $t$ is the number of years between censuses. To simplify the model, growth was calculated as the annual probability of a stem transitioning into the next larger $10-\mathrm{cm}$ dbh class. The transition rate, $T$, for a given size class was calculated in a manner similar to the mortality rate:

(2) $T=1-\left(G_{t} / N_{0}\right)^{1 / t}$

where $N_{0}$ is the number of stems alive at time $=0, G_{t}$ is the number of stems from the original cohort that did not grow into the next size class (i.e., either died or remained alive but stayed in the same size class), and $t$ is the number of years between censuses. To calculate annual recruitment we started with the measured number of new stems $\geq 5$ $\mathrm{cm}$ dbh divided by the number of years between censuses. We adjusted this rate upwards to account for stems that reached at least $5 \mathrm{~cm}$ dbh but then died before being censused, using the formula 
(3) $R_{A}=R_{m}\left(\sum\left(\left(t-t_{i}\right)\left(M_{m}\right)^{t} i\right)\right)$

where $R_{A}$ is the adjusted recruitment rate, $R_{m}$ is the measured recruitment rate, $M_{m}$ is the measured mortality rate for stems $5-10 \mathrm{~cm} \mathrm{dbh,} t$ is the number of years between censuses and $t_{i}$ is the number of years until the next census.

Because the four Davis plots differed in the number of years between censuses, we calculated recruitment, transition, and mortality rates by individual plots before combining those rates to create an overall rate by weighting based on the number of stems in each plot. To run the model, we started with our 2006 stem counts for each species, then created stem counts for the subsequent year by giving each individual stem a random chance to either die or transition into the next larger size group based on the transition and mortality rates calculated above, with new trees added to the smallest size class based on the adjusted recruitment rate. Because we were most interested in the implications of different recruitment rates on the forest, and because recruitment rates changed more during our study than transition or mortality rates, we ran the model twice for each species, once each for the adjusted recruitment rates for the intervals between the first and second censuses and between the second and third censuses. Using the measured rates as probabilities and starting with the size distributions from the 2006 census we ran 100 iterations, calculating annual changes in composition out to 1000 years, at which point all simulation runs had converged on equilibrium basal areas. To convert stem counts to basal area we calculated the average basal area for each size class based on the assumption that stem sizes were evenly distributed within the size class.

\section{Results}

\section{Davis Plots}

\section{Relative Composition by Size-Class}

Together, sugar maple, hemlock and yellow birch comprised $>78 \%$ of the total stems in every size class in every census, but the relative composition (RC) of each of the three species varied among size classes and censuses (Fig. 1). More than $65 \%$ of stems 5-15 cm dbh were sugar maple. Relative composition was more evenly distributed 
among sugar maple, hemlock, and yellow birch in the larger size classes. Between the first and third censuses, the RC of sugar maple stems 5-35 cm dbh increased. In contrast, the RC of yellow birch at every size class decreased between censuses, with the greatest declines at the largest size classes. Hemlock was more variable. The RC of hemlock 5$25 \mathrm{~cm}$ dbh declined between the first and third censuses. The RC of intermediate-sized hemlocks remained stable, while the RC increased for size classes larger than $45 \mathrm{~cm} \mathrm{dbh}$.

The relative composition of seedlings and saplings shifted minimally. Sugar maple was the dominant species at all sizes in all censuses. It represented $>90 \%$ of the stems in every seedling height class $(0-50 \mathrm{~cm}, 50-100 \mathrm{~cm}$, and 100-200 cm) in the 1991 census of the subplots in plots B, C, and D combined. In these three plots in 2006, sugar maple comprised $89 \%$ of seedlings $0-50 \mathrm{~cm}$ tall, $98 \%$ of stems $50-100 \mathrm{~cm}$ tall, and $100 \%$ of stems 100-200 cm tall. There were no hemlock seedlings $>50 \mathrm{~cm}$ in height in either census. In 1991 there were no yellow birch seedlings $>100 \mathrm{~cm}$ in height, and in 2006 there were none $>50 \mathrm{~cm}$ in height. The subplots in plot A showed similar trends (data not shown). In total, sugar maple comprised $>95 \%$ of all stems $<2 \mathrm{~m}$ tall in 1990 and 2006. Sugar maple comprised $>75 \%$ of all saplings (stems $>2 \mathrm{~m}$ tall, but $<5 \mathrm{~cm} \mathrm{dbh}$ ) in both the second and third censuses, whereas hemlock and yellow birch represented $<1 \%$ and $<3 \%$, respectively, of all saplings in both censuses.

\section{Mortality}

There were no fires or major wind disturbances in our plots during the study period. Mortality was likely due to age, local disturbances, and other stochastic events. The three most abundant species, hemlock, sugar maple, and yellow birch, all exhibited "boat-shaped" mortality curves, with high mortality in the 5-15 cm dbh class, low mortality at intermediate size classes, and increasing mortality in the largest size classes (Fig. 2). In most size classes, yellow birch had the highest mortality rate, followed by sugar maple and hemlock.

\section{Recruitment}

Adjusting for mortality between censuses created up to a $300 \%$ increase in annual rates of recruitment of stems into the $\geq 5 \mathrm{~cm}$ dbh class compared to observed recruitment rates, but there was little shift in the relative rates among hemlock, sugar maple, and 
yellow birch. In both census intervals sugar maple averaged at least 20 times more new recruits/ha than either hemlock or yellow birch. Hemlock recruitment declined from 0.06 to 0.03 new recruits ha $^{-1}$ year $^{-1}$ and sugar maple recruitment declined from 3.29 to 2.25 new recruits ha $^{-1}$ year $^{-1}$. Yellow birch, on the other hand, increased from 0.06 to 0.11 new recruits $\mathrm{ha}^{-1}$ year $^{-1}$.

\section{Shifts in Stem Density}

For all species combined, the number of stems in the smallest size classes declined over the course of the study, while the number of stems at the largest size classes increased (data not shown). The numbers of stems 5-15 cm dbh declined by $21 \%$. Trends were less clear for intermediate size classes, with no $10 \mathrm{~cm}$ dbh class shifting by more than $7 \%$. Stems $>55 \mathrm{~cm}$ dbh increased by $21 \%$. In the second and third censuses there were 590 and 1102 new stems above $>5 \mathrm{~cm}$ dbh, respectively, with sugar maple comprising $>70 \%$ of these stems in both censuses.

Between the second and third census, the total density of all saplings combined decreased by $50 \%$ (Fig. 3). Total seedling stem density declined by more than $80 \%$ in the small height classes of 0-50 cm, 50-100 cm, and 100-200 cm between 1991 and 2006 (Fig. 3). The sum of the averages of percent cover for each woody species in the subplots declined from $41 \%$ in 1991 to $7 \%$ in 2006. Since estimates were obtained for each species individually, these numbers would be higher than a measure of percent cover of all species taken at once, where overlapping leaves of different species would not be counted twice.

\section{Earthworms}

We found earthworms at 44 of the 68 locations surveyed in the Davis plots, including locations in each of the four plots. All of the earthworms belonged to one species, Dendrobaena octaedra.

\section{Deer Browse Preference and Size-Class Distribution}

Species differed in whether their size-class distribution followed a classic "reverse J" or rotated sigmoid shape typical of late-successional old-growth forests (Frelich 2002). In the third census, each of the eight species classified as unpreferred browse by Dahlberg and Guettinger (1956) had more stems in the 5-15 cm dbh class than in any 
larger class (Fig. 4a). Of the seven preferred-browse species, only one, red maple (Acer rubrum), had more stems in the smallest size class than in any larger size class (Fig. 4b). Except for red maple, the counts for preferred species had their highest density at intermediate size classes.

There were more new recruits (stems that had grown to $\geq 5 \mathrm{~cm} \mathrm{dbh}$ ) of unpreferred browse species than preferred browse species in both the second and third censuses. There were 6 new recruits of unpreferred browse species in the second census per 100 trees of unpreferred species in the first census, while the ratio for preferred species was 1:100. There were 11 new recruits of unpreferred species in the third census per 100 trees of unpreferred species in the second census, while the ratio for preferred species was 2:100. The ratio of new recruits to trees that died among preferred browse species was 19:100 for the second census and 18:100 for the third census, compared to ratios for unpreferred browse species of 84:100 and 59:100 for the second and third censuses, respectively.

\section{Stearns and Sotala Plots}

In the 1974-75 census, sugar maple stems $>2.54 \mathrm{~cm}$ dbh were recorded at 6 of the 8 sites, hemlock stems at 7 sites and yellow birch stems at 6 sites. Although most sites had only limited change in the canopy, by 2009 hemlock had disappeared from one of the sites where it had been present and yellow birch had disappeared from two sites.

Over a longer time period and at a wider variety of sites throughout the Sylvania Wilderness, regeneration trends in the Stearns and Sotala plots corroborate trends found in the Davis plots. The Stearns and Sotala plots all had either steeply declining or consistently low regeneration between census intervals, with sugar maple comprising a disproportionate fraction of the regeneration compared to its abundance in the canopy. Sugar maple comprised $>90 \%$ of all stems $>0.91 \mathrm{~m}$ tall but less than $2.54 \mathrm{~cm}$ dbh in the subplots in the first two censuses, and was the only species found in any subplot in 2009. Seven of the eight sites had at least one sugar maple sapling in a subplot in both 1974-75 and 1990. Across all plots, the total number of sugar maple saplings declined from 304 to 189 between the 1974-75 and 1990 censuses. In 2009 there were only a total of three sugar maple saplings, on two sites. All three stems were $>2 \mathrm{~m}$ in height. No other 
species had more than six saplings in any census, and no hemlock saplings were found in any of the plots.

\section{Demographics Model}

Our demographics model predicts that if observed rates of recruitment, growth, and mortality in the Davis plots continue, at equilibrium there would be little to no hemlock and yellow birch remaining in the forest, while the basal area (BA) of sugar maple would remain similar to its current level (Fig. 5). In all runs, the population approached equilibrium within 500 years, at which time all of the stems present at year 0 had died. Results differed to a moderate degree depending on whether the model used the recruitment rates from the first to second census or the second to third census. Using the first recruitment rate for sugar maple yielded a BA of $15.2 \mathrm{~m}^{2} \mathrm{ha}^{-1}$, slightly higher than the observed BA of $12.2 \mathrm{~m}^{2} \mathrm{ha}^{-1}$ from the third census, while the second recruitment rate yielded a lower BA of $10.4 \mathrm{~m}^{2} \mathrm{ha}^{-1}$. Predicted hemlock BA was $0.8 \mathrm{~m}^{2} \mathrm{ha}^{-1}$ and $0.4 \mathrm{~m}^{2}$ $\mathrm{ha}^{-1}$ for the first and second census intervals, respectively, in both cases a sharp decline from hemlock's third census observed BA of $12.9 \mathrm{~m}^{2} \mathrm{ha}^{-1}$. Yellow birch BA was $0.1 \mathrm{~m}^{2}$ $\mathrm{ha}^{-1}$ and $0.2 \mathrm{~m}^{2} \mathrm{ha}^{-1}$, for the first and second census intervals, respectively, again much below the observed BA of $8.8 \mathrm{~m}^{2} \mathrm{ha}^{-1}$ in the third census. Thus the combined basal area of the three dominant tree species declined from a third census value of $33.9 \mathrm{~m}^{2} \mathrm{ha}^{-1}$ to 16.1 or $11 \mathrm{~m}^{2} \mathrm{ha}^{-1}$, depending on model parameters.

We approximated the recruitment rates that would be required for each species to maintain the observed BA from the third census. We ran the model using different recruitment rates to estimate that rate to the nearest 0.1 new stems $\mathrm{ha}^{-1}$ year $^{-1}$ that after 1000 years most closely approximated the BA measured in the third census. These were 1.0, 2.9, and 4.8 new recruits ha $^{-1}$ year $^{-1}$ for hemlock, sugar maple, and yellow birch, respectively.

\section{Discussion}

Old-growth forests of the eastern United States hold social value as places to encounter "wilder" (i.e., less human-altered) nature, and environmental value as a rare habitat and a template for restoration of more disturbed sites. Although they have never been clear-cut, old-growth forests in the Great Lakes region may be changing due to 
multiple anthropogenic factors including elevated deer browsing, exotic earthworm invasion and climate change (Frelich and Reich 2009). Two multi-decadal sets of permanent plots in the old-growth forests of Sylvania Wilderness in Northern Michigan show virtually no recruitment for preferred deer browse species including cedar, hemlock and yellow birch extending back at least to the 1970's. This recruitment limitation is slowly altering the structure and composition of the forest canopy (Fig. 4).

In this study, all tree species classified as unpreferred browse had size distributions characteristic of late-successional forests (i.e., highest densities in the smallest size classes). In contrast, all but one of the preferred browse species had their highest density at intermediate size classes, suggesting that recruitment of these species has declined in recent decades (Fig. 4). Both preferred browse species and unpreferred browse species ranged from medium to highly shade-tolerant and varied considerably in drought tolerance, (Niinemets and Valladares 2006), suggesting that recent disturbance or climate patterns were not the dominant force in determining which species regenerated well or poorly.

The one species that did not follow general trends of size distribution was red maple, which had its highest stem density in the smallest size class, despite being ranked as highly preferred browse. This is probably due to red maple's bimodal habitat distribution; it is found on well drained upland soils where it can grow to a canopy tree $>50 \mathrm{~cm} \mathrm{dbh}$, but it is also very dense within low wetlands in our plots, where it rarely exceeds $15 \mathrm{~cm}$ dbh. In the one Davis plot without any wetland areas the size-class distribution of red maple was similar to that of other preferred browse species: it was three times more abundant in the $35-45 \mathrm{~cm}$ dbh size class than in the $5-15 \mathrm{~cm}$ dbh size class. Thus, red maple does follow the predicted pattern of effects by deer browsing when upland forests are considered separately.

Our results provide support for previously published studies that demonstrate that high deer populations and recruitment failure of hemlock in the region around Sylvania Wilderness extend back to the 1940's (Leopold 1943, Graham 1954, Frelich and Lorimer 1985). Stand histories reconstructed using tree rings show regular hemlock recruitment and episodic yellow birch recruitment in Sylvania and other unlogged forest remnants in 
the surrounding region from the oldest reconstructed period in the mid-1700's until the mid-1900's, while regular sugar maple recruitment continued at least to the end of the 1980’s (Frelich and Lorimer 1991, Parshall 1993, Frelich and Graumlich 1994).

Long-term lack of recruitment stemming from high deer populations, eventually leading to change in the composition of the forest overstory, has also been shown in numerous temperate forests around the world. For example, deer give the advantage to black cherry (Prunus serotina) over sugar maple in Pennsylvania, USA (Horsley et al 2003), and are strongly implicated as the cause of compositional shifts in woodlands of New Zealand (Husheer et al 2003), Great Britain (Fuller and Gill 2001), and Poland (Kuijper et al. 2010).

White-tailed deer have been shown to shift to less preferred species after more preferred species are mostly cleared from the landscape in the Apostle Islands in Wisconsin (Beals et al. 1960) and Anticosti Island in Quebec (Tremblay et al. 2005). We hypothesize that a similar process has occurred in Sylvania. By the time of the establishment of the Stearns plots in 1974-75, selective browsing of hemlock and yellow birch had already virtually eliminated those species from the understory, forcing deer to turn to sugar maple for winter forage. Photos and field observations from 1987 to 1991 in the Davis and Stearns plots show that most hardwood stands had a dense seedling layer dominated by heavily browsed but annually resprouting sugar maple stems (Fig. 6a). In 2006 and 2009 the vast majority of remaining sugar maple seedlings greater than $0.5-\mathrm{m}$ tall had been browsed by deer, often multiple times (personal observation). A rising deer to seedling ratio may have led to an accelerated loss of seedlings as the remaining stems became subject to more intense browsing (Augustine and Frelich 1998), leading to a large reduction in the density of the sugar maple seedling layer by 2006 (Fig. 6b).

The demographics model shows that if current rates of growth, recruitment, and mortality were to continue into the future, larger size classes would become increasingly like the seedling and sapling layer: sparse and maple dominated. The model indicates that, to maintain their basal area from 2006 in the future, hemlock and yellow birch would require a recruitment rate 17 and 39 times higher, respectively, than the higher of the recruitment rates observed between censuses. Unlike hemlock and yellow birch, the 
demographics model shows that sugar maple could maintain its basal area with current observed recruitment rates, although the recent decline in seedling abundance could be a harbinger of future reduced recruitment.

Several factors in addition to deer browsing could prevent sugar maple and other species from replacing hemlock and yellow birch. First, although the climate has only changed slightly over the last century, this is not likely to be the case in the future. Much warmer, effectively drier summers are projected for the area over the next century (Wuebbles and Hayhoe 2004), which could increase mortality and perhaps place Sylvania outside the current climate range of a number of species found there today, including hemlock, white spruce, black spruce, tamarack, white cedar, and balsam fir, that are near their southern or western range limit in Sylvania (Prasad et al. 2010, Walker et al. 2002). Sugar maple could also be affected by increased dryness associated with warmer, drier summers, since its optimum site characteristics include silty soils with high water holding capacity and cation exchange capacity, and its presence on the sandy, relatively nutrient poor soils in places like Sylvania benefits from a cool climate with frequent recharge of the soil water (Godman et al. 1990, Henne et al. 2007).

A second factor with likely negative consequences for sugar maple is European earthworm invasion. The invasion of sugar maple forests in this region by Lumbricus terrestris and L. rubellus has been linked to recruitment failure by altering seedbed conditions, changing the mycorrhizal community, and reducing $\mathrm{N}$ and $\mathrm{P}$ availability, particularly when combined with the effects of deer browsing (Frelich et al. 2006). Dendrobaena octaedra, the only earthworm species we found on the Davis plots, has only minor impacts on seed germination and seedling survival (Holdsworth et al. 2007). However, Lumbricus earthworms are common around Sylvania's lakeshores, and are now present within $0.5 \mathrm{~km}$ of two of the Davis plots (personal observation).

Our data suggest that changing recruitment patterns caused by high seedling mortality are altering the structure and species composition of the Sylvania forest, and deer browsing is likely the major cause. Two of the dominant species, hemlock and yellow birch, are highly preferred by deer and their diameter distributions (Fig. 4) are not the descending monotonic shape typical of old-growth forests. A third dominant species, 
sugar maple, has maintained sufficient recruitment to maintain its historic abundance and diameter distribution, but it could be affected by continued heavy deer browse, climate change, and the spread of Lumbricus earthworms (Holdsworth et al. 2007, Frelich and Reich 2010).

Of the three major agents of change impacting the future of Sylvania forests, deer browsing, earthworm invasion, and climate change, deer browsing appears to be the factor that has had the biggest impact in the late $20^{\text {th }}$ century, is expected to exacerbate the impacts of earthworm invasion and climate change in the future (Holdsworth et al. 2007, Frelich and Reich 2010), and is the only factor of the three that can be effectively managed at the current time. Therefore, active management to counter the impacts of high deer populations (which are in part a response to human changes on the landscape) is necessary to maintain historically "natural" dynamics that have maintained this forest for millennia (Davis et al. 1998). In Sylvania, management policies that reduce the deer herd, such as protecting populations of wolves and cougars, lengthening the antlerless deer hunting season, hiring sharpshooters, and encouraging the community to stop feeding deer and to hunt antlerless deer would likely allow hemlock, yellow birch, and other species to recover. Continued research on these permanent plots will be key for identifying the impacts of future environmental changes as well as potential management strategies in old-growth forest. 
Table 1. The browse preference rankings of Dahlberg and Guettinger (1956) for species with more than 10 stems $>5 \mathrm{~cm}$ dbh in 2006 in the Davis plots in Sylvania Wilderness, Michigan. Species range from most preferred (I) to least preferred (IV) browse. We categorized species ranked I, II or II-III as "preferred browse" and species ranked III, IIIIV or IV as "unpreferred browse".

\begin{tabular}{lc}
\multicolumn{1}{c}{ Species } & $\begin{array}{c}\text { Browse Preference Rating } \\
\text { (Dahlberg and Guettinger 1956) }\end{array}$ \\
\hline White Cedar (Thuja occidentalis) & I \\
Hemlock (Tsuga canadensis) & I \\
Red Maple (Acer rubrum) & I \\
Basswood (Tilia americana) & II \\
White Pine (Pinus strobus) & II \\
Yellow Birch (Betula alleghaniensis) & II \\
Black Ash (Fraxinus nigra) & II-III \\
American Elm (Ulmus americana) & III \\
Balsam Fir (Abies balsamea) & III \\
Sugar Maple (Acer saccharum) & III \\
White Ash (Fraxinus americana) & III \\
Hop Hornbeam (Ostrya virginiana) & III-IV \\
Black Spruce (Picea mariana) & IV \\
Tamarack (Larix laricina) & IV \\
White Spruce (Picea glauca) & IV \\
Green Ash (Fraxinus pennsylvanica) & not ranked
\end{tabular}




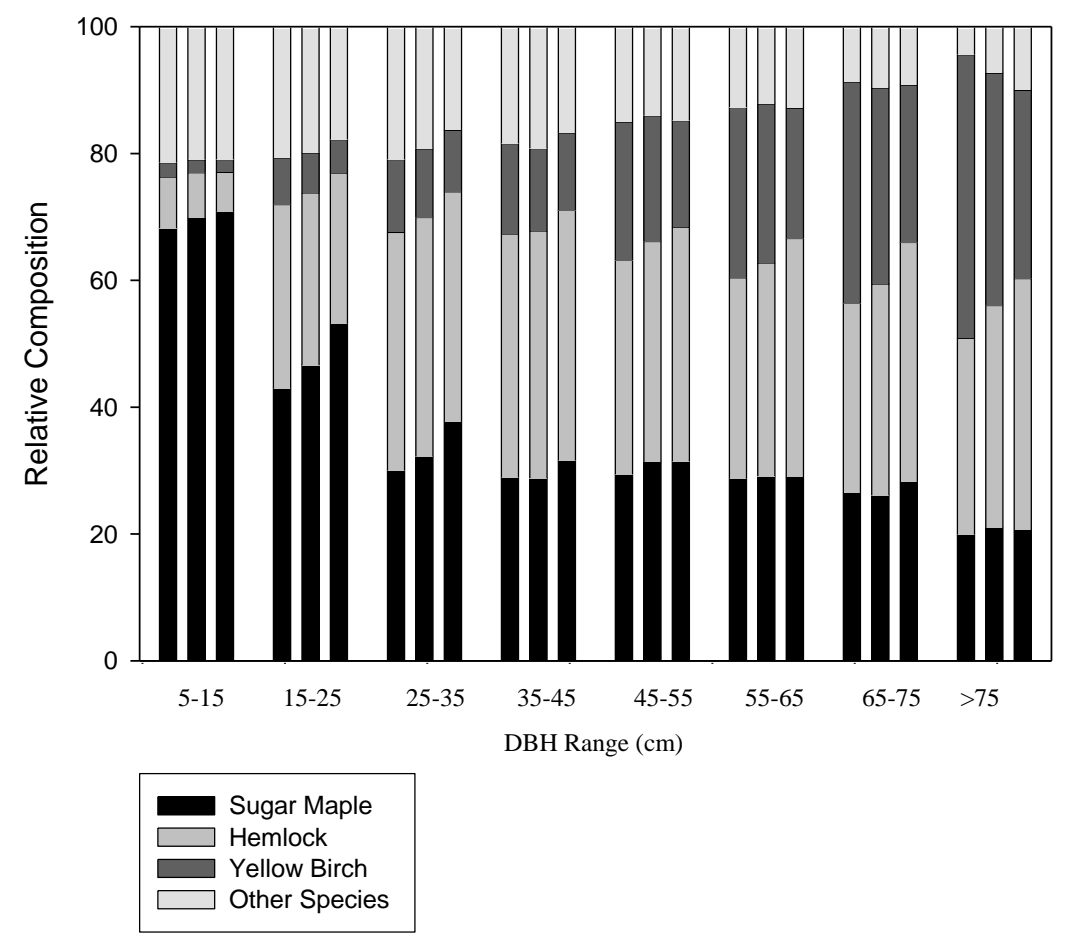

Fig. 1. The relative composition of the three most common tree species in the Davis plots in Sylvania Wilderness, Michigan. The three bars at each DBH size class represent, in order, the first (1987-90), second (1993-95) and third censuses (2006). 


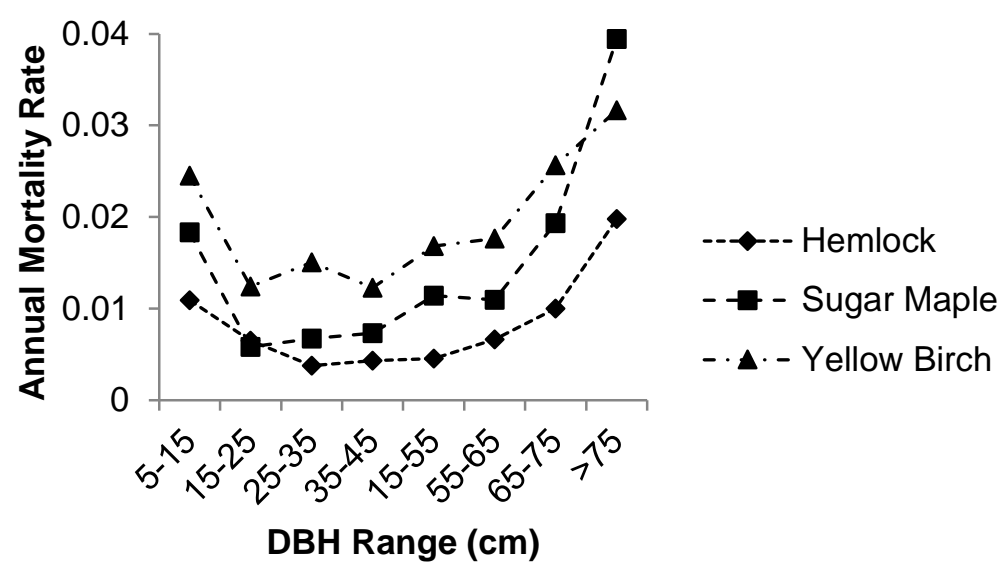

Fig. 2. The annual mortality rate by original size class in the Davis plots in Sylvania Wilderness, Michigan, between the first (1987-90) and third census (2006) for the three most abundant species. 

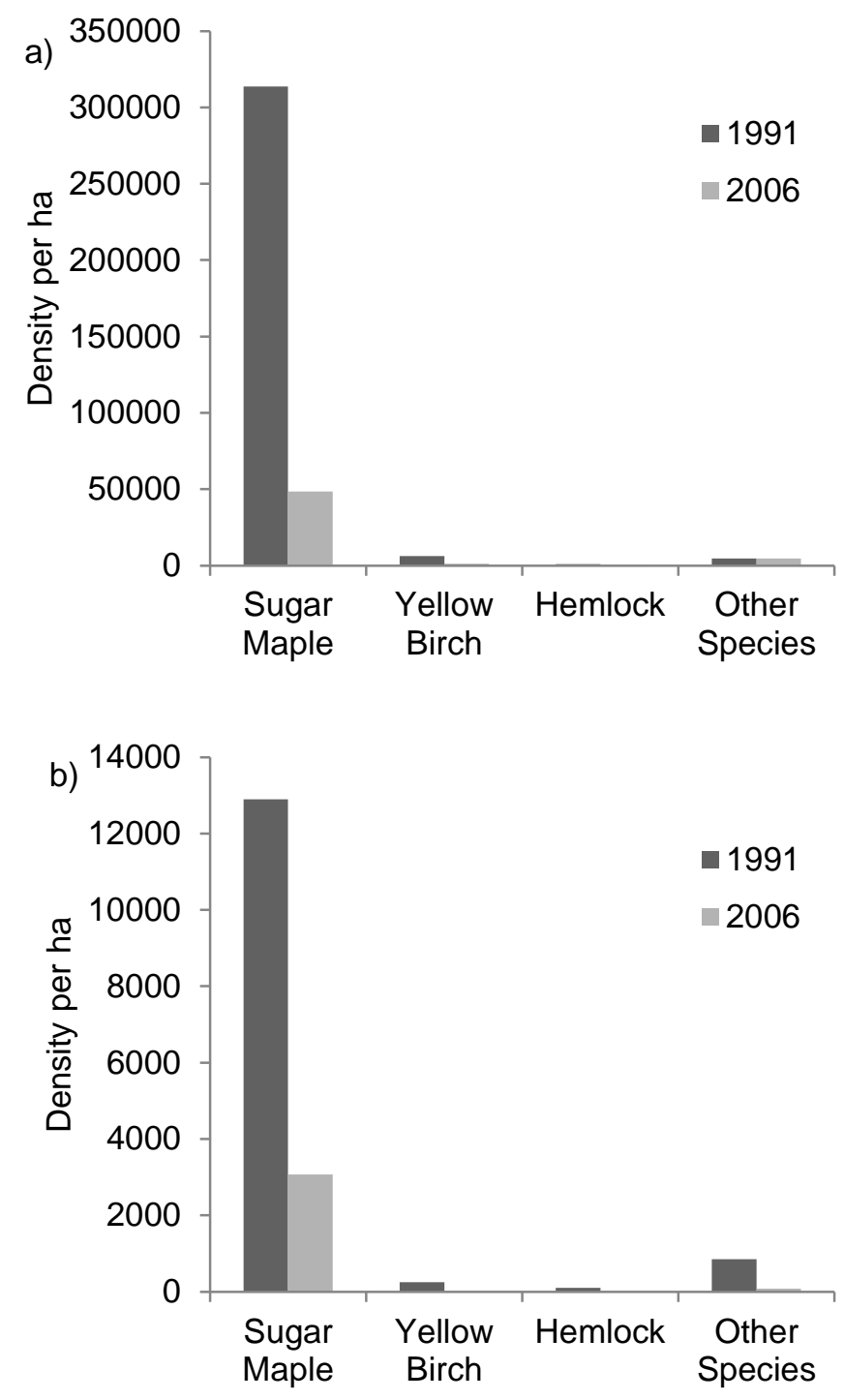

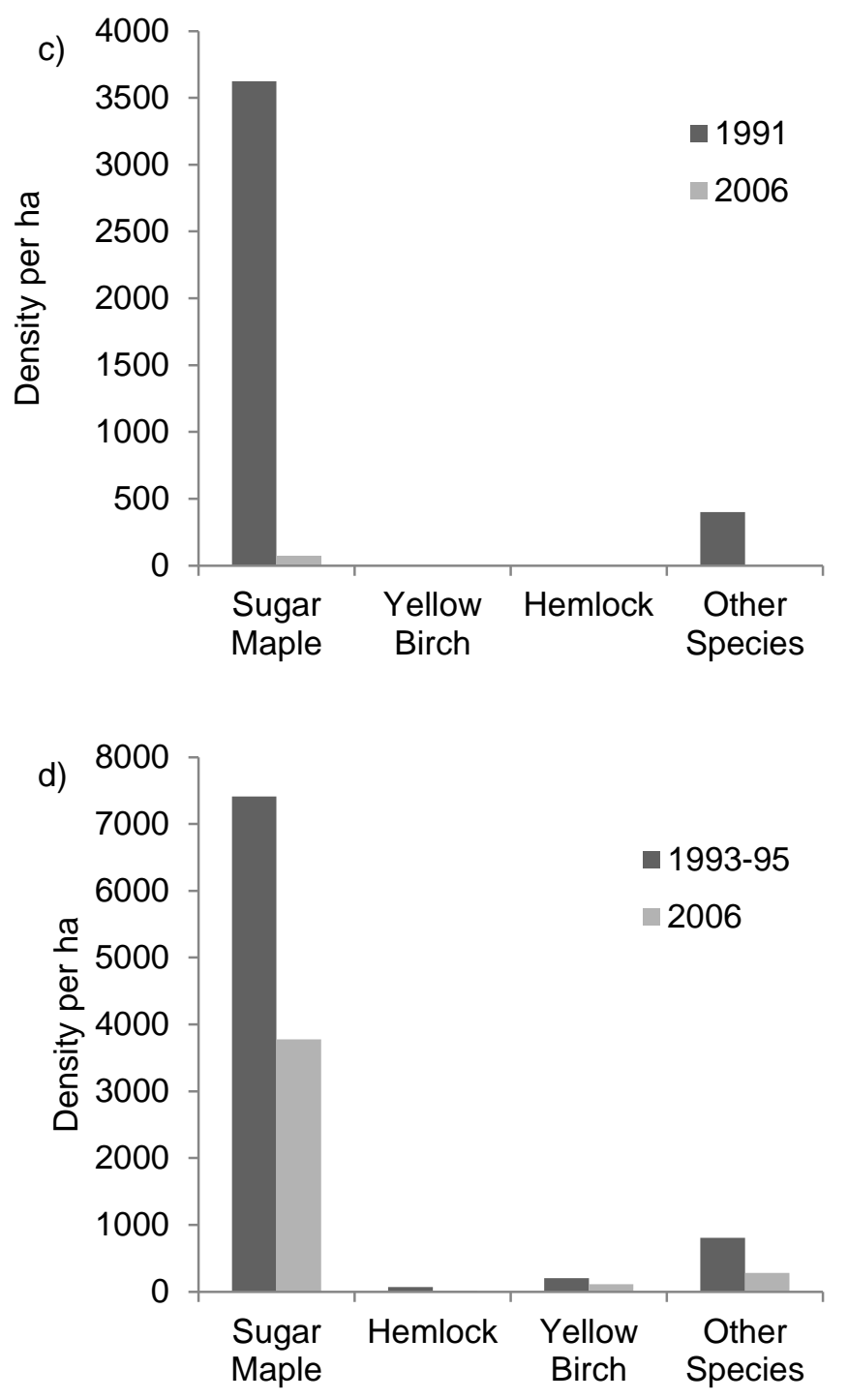

Fig. 3. The density of seedlings across three of the Davis plots in Sylvania Wilderness, Michigan, in 1991 (black) and 2006 (gray) in height classes of (a) 0-50 cm (b) 50-100 $\mathrm{cm}$, and (c)100-200 cm and (d) the density of saplings (stems $>2 \mathrm{~m}$ tall but $<5 \mathrm{~cm} \mathrm{dbh}$ ) across all four Davis plots in 1993-95 (black) and 2006 (gray). Note that each panel has a different $y$-axis scale. 
a)

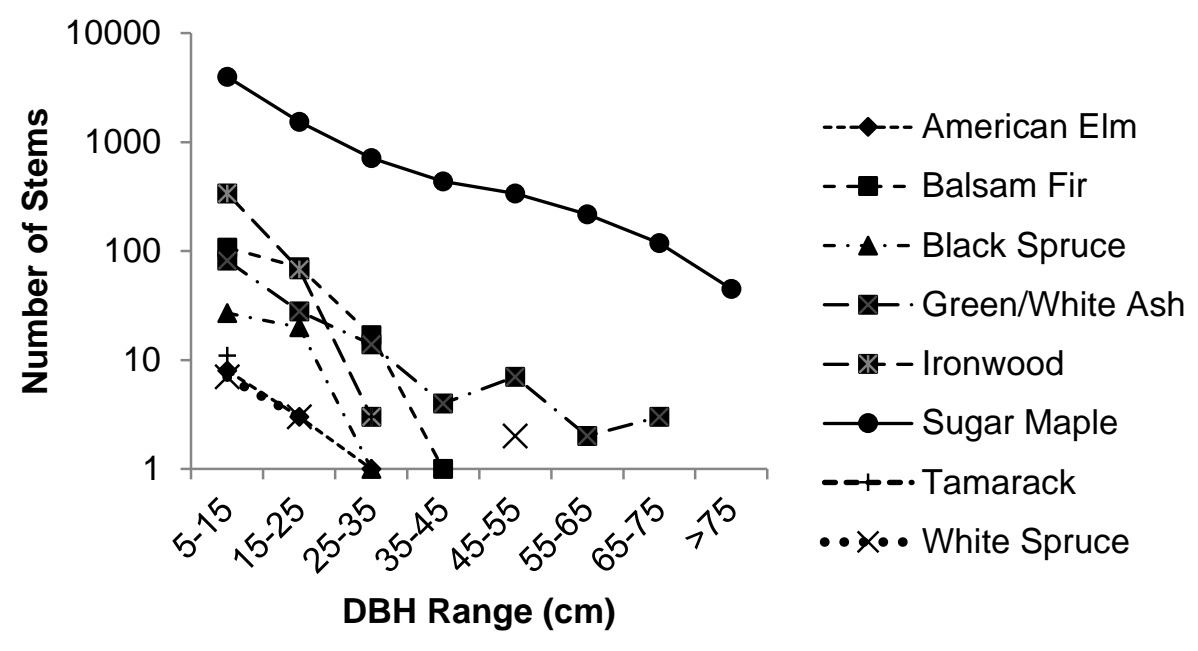

b)

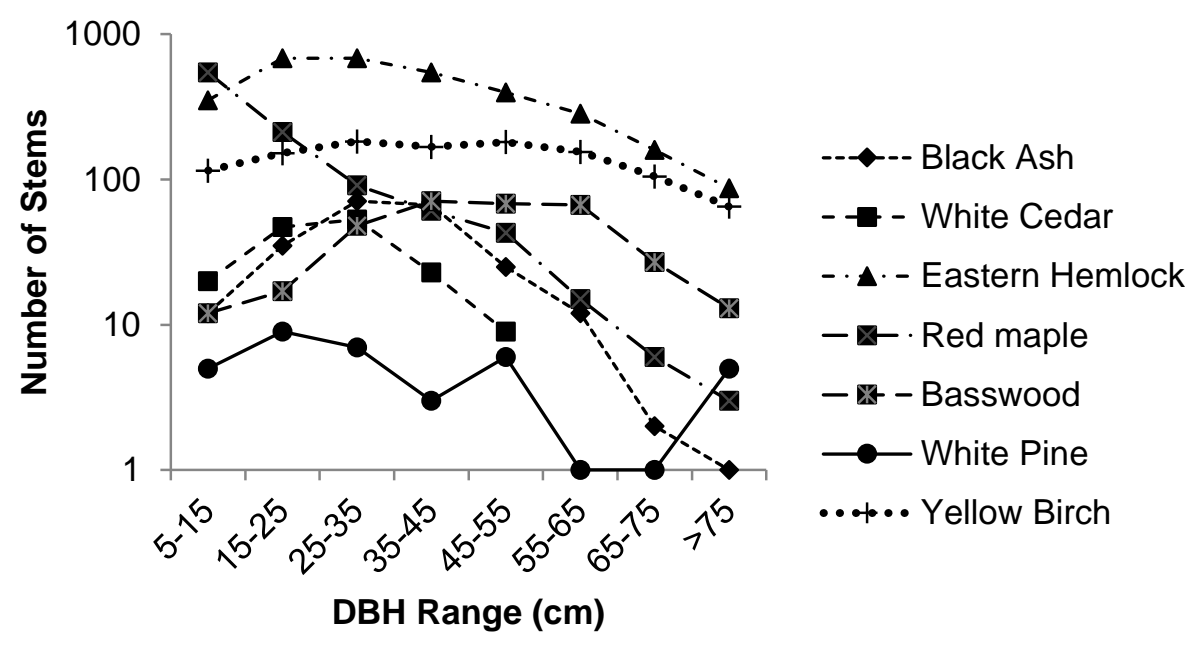

Fig. 4. The total number of stems in the Davis plots in Sylvania Wilderness, Michigan by species in $10 \mathrm{~cm}$ DBH size classes. Species in a) are unpreferred browse and species in b) are preferred browse. Data are from the third census (2006). 
a) Yellow Birch, 0.06 stems/ha/year

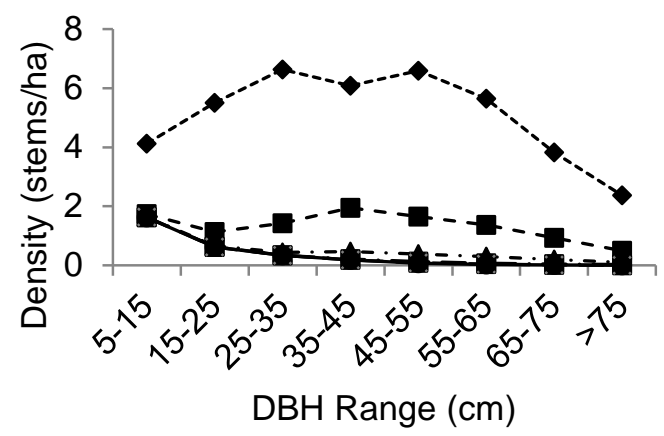

b) Hemlock, 0.06 stems/ha/year

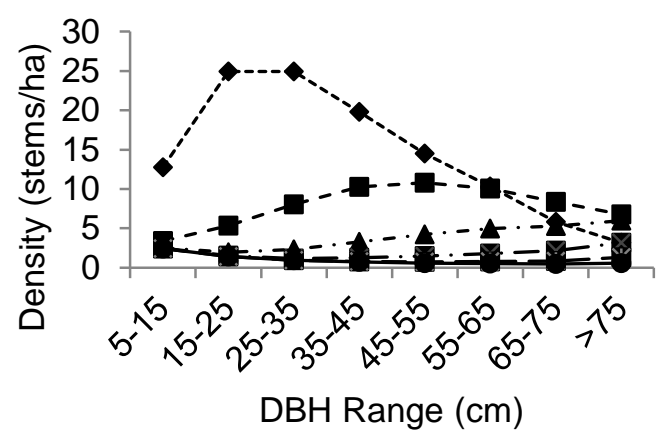

c) Sugar Maple, 3.28 stems/ha/year

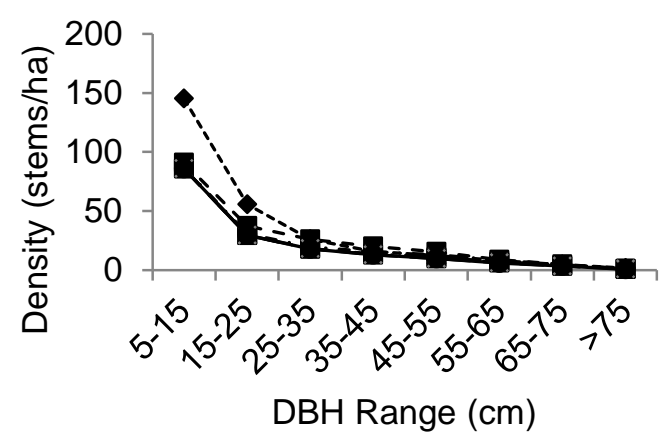

d) Yellow Birch, 0.11 stems/ha/year

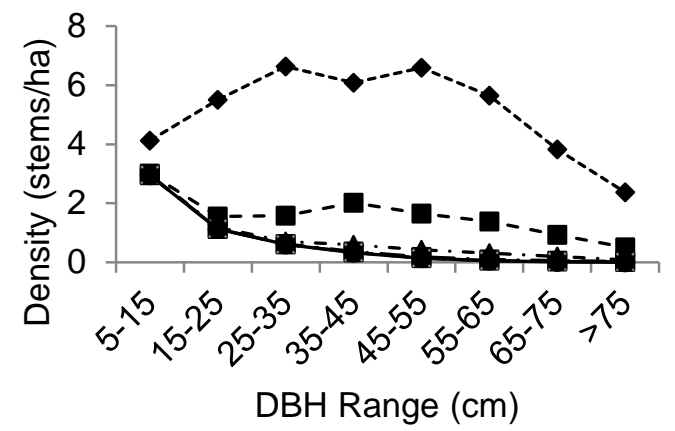

e) Hemlock, 0.03 stems/ha/year

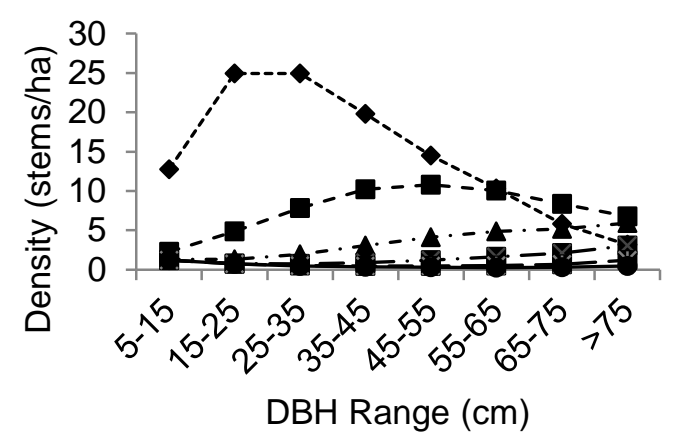

f) Sugar Maple, 2.22 stems/ha/year

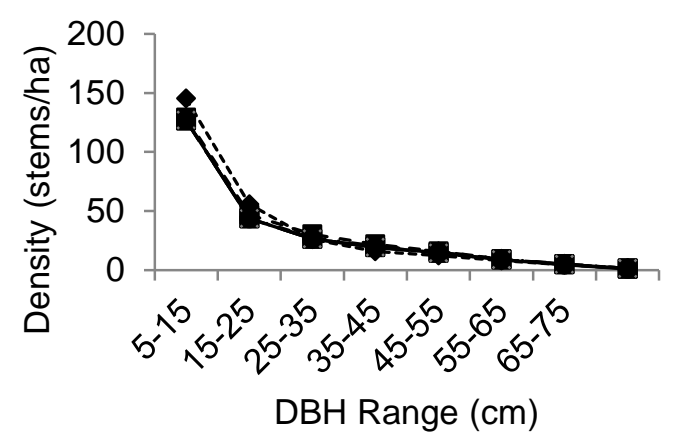


Fig. 5. Measured and future predicted size distribution curves for hemlock, sugar maple, and yellow birch in the Davis Plots in Sylvania Wilderness, Michigan. 

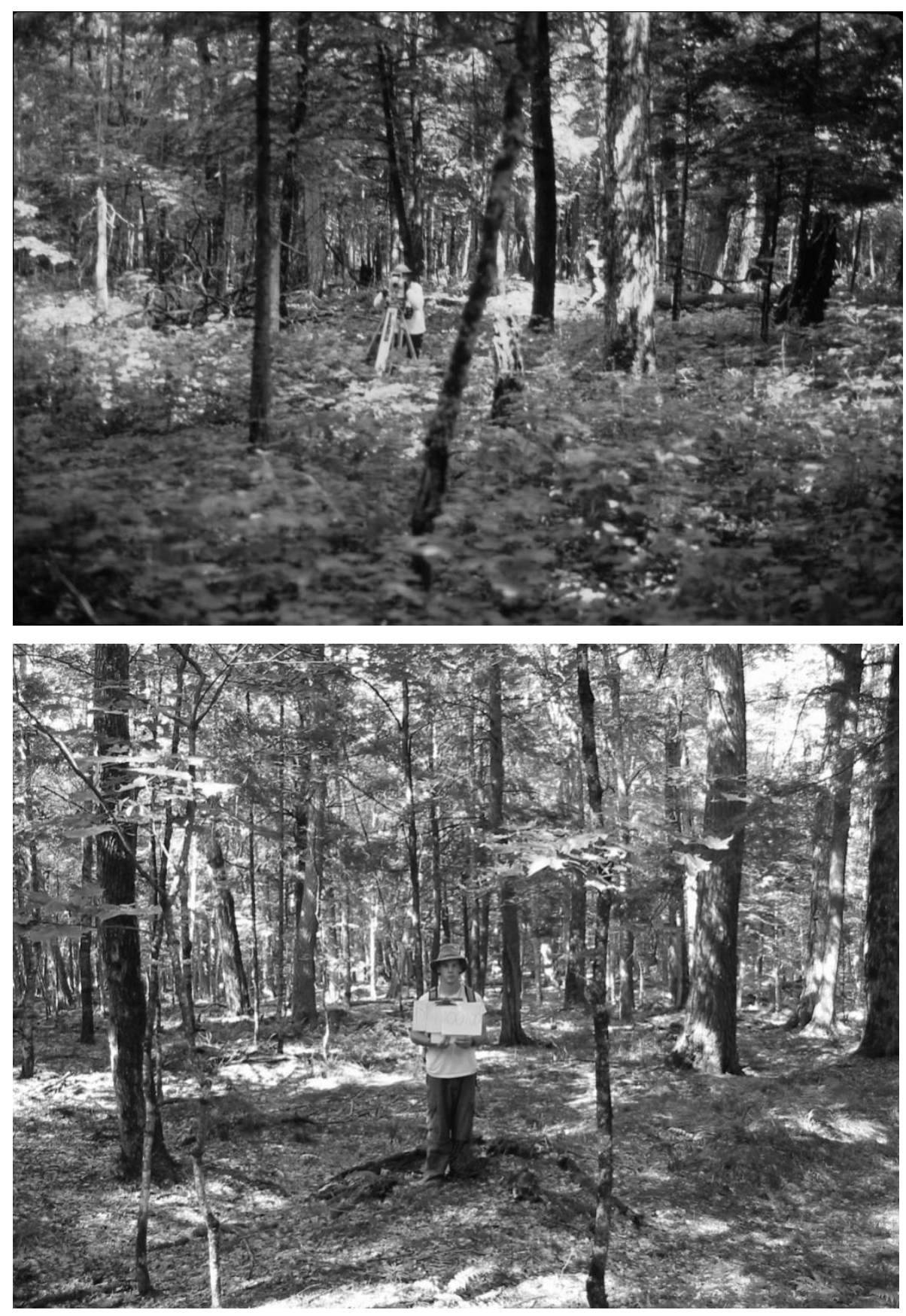

Fig. 6. Photos from one of the Davis plots in Sylvania Wilderness, Michigan from 1990 (top) and 2006 (bottom), showing the decline in forest floor vegetation. Photos are of different, but representative, locations within the same 5-ha plot. In the 25 subplots in this plot in 1991 there were 44 sugar maple $/ \mathrm{m}^{2}<50 \mathrm{~cm}$ tall and 0.7 sugar maple $/ \mathrm{m}^{2} 50$ $200 \mathrm{~cm}$ tall; in 2006 there were 0.7 sugar maple $/ \mathrm{m}^{2}<50 \mathrm{~cm}$ tall and no sugar maple 50$200 \mathrm{~cm}$ tall in any of the subplots. There were no hemlock or yellow birch 50-200 cm 
tall in either census. In 1991 there were 0.46 yellow birch $/ \mathrm{m}^{2}$ and 0.04 hemlock $/ \mathrm{m}^{2}<50$ $\mathrm{cm}$ tall; in 2006 those numbers were 0.12 and 0.0 respectively. 
Chapter 2: No Observed Impact of Coring on Diameter Growth or Mortality of Trees in an Old-Growth Hemlock-Hardwood Forest 


\section{Introduction}

Ecological research often finds that seemingly minor variations in the environment can have large effects on organisms and communities. Conscientious ecologists may wonder whether their own research activities could have an impact on the ecosystem. This would be of special concern when the study organism or system is endangered or given high cultural value, when researchers are working in a preserve with management objectives of minimizing human impacts, or when the impact could affect the results of future studies at the same site.

There have been a few documented examples of ecological research unintentionally affecting the study system. In an intensively studied tropical research plot (the 50-ha plot on Barro Colorado Island, Panama), the survival of tree and liana seedlings during a census year was reduced by trampling from field researchers (Comita and Goldsmith 2008, Comita et al. 2009). There have also been cases where repeatedly visiting and touching herbaceous plants affected their herbivory and mortality rates (Cahill et al. 2001, Gadotti and Batalha 2010), although the extent of these impacts has been debated (Schnitzer et al. 2002).

Tree coring, or increment boring, the removal of a thin cylinder of wood from the trunk of a tree to examine the tree's growth rings, has been a standard technique in ecological, silvicultural, and climatological research since the $19^{\text {th }}$ century, providing valuable information about stand development, growth rates, and past climate. Despite its usefulness, some researchers have urged caution when deciding to core trees on the chance that coring could be harmful (e.g., Harris et al. 2009). This would be especially important in permanent plots where growth and mortality are measured repeatedly over many years. Also, for certain research questions the best source for information may come from exceptionally large or old trees, but these trees may hold special cultural or environmental value.

Previous work has found increased fungal infection in a number of common temperate forest species in the wood surrounding a tree-corer created borehole (Hepting et al. 1949, Laflamme 1979, Lorenz 1944). The only study we are aware of to compare the mortality of cored and uncored trees, van Mantgem and Stephenson (2004), found no 
effect of tree coring on mortality in a fir (Abies concolor and A. magnifica) forest in the Sierra Nevada of California. However, this study compared plots, two where all trees were cored and two where all trees were uncored, with the cored and uncored plots being up to several kilometers apart, so mortality rates may have been affected by differences in the environment or stand history. Further, it only examined two congeneric species, leaving open the possibility that other species are more susceptible to harm from tree coring.

In this study we compared the growth and survival of diverse species of cored and uncored trees over 16-18 years in a late-successional hemlock-hardwood forest. We expected that, despite our large data set, we would find no evidence to reject the hypothesis that coring has no effect on the growth or mortality of trees.

\section{Methods}

Our study site is the unlogged, late-successional forest in Sylvania Wilderness Area, a unit of Ottawa National Forest in Michigan's Upper Peninsula (46 $13^{\prime} \mathrm{N}, 89^{\circ} 18^{\prime}$ W). The climate is cool continental with a mean of $812 \mathrm{~mm}$ of annual precipitation and annual mean daily high and low temperatures of $10^{\circ} \mathrm{C}$ and $-2^{\circ} \mathrm{C}$, respectively. The predominant upland ecosystem in Sylvania is the hemlock-hardwood forest. Eastern hemlock (Tsuga canadensis), sugar maple (Acer saccharum), and yellow birch (Betula alleghaniensis) dominate the canopy, with smaller numbers of basswood (Tilia americana), ash (Fraxinus spp.), red maple (Acer rubrum), and white pine (Pinus strobus). Common subcanopy species include hop hornbeam (Ostrya virginiana) and northern white cedar (Thuja occidentalis). Trees can exceed 300 years in age, and grow to $1 \mathrm{~m}$ in diameter.

Four multi-hectare mapped plots were established in the Sylvania forest between 1987 and 1990 by Margaret Davis and her associates of the University of Minnesota. The plots range from 5 to 10 ha in size, with a total area of 27.45 ha. While these plots consist mainly of upland hemlock-hardwood forest, there are also a few small bogs, ash wetlands, and ponds. Plot locations were originally selected to contain different spatial patterns of diversity and to include small ponds and hollows suitable for paleoecological research (Frelich et al. 1993, Davis et al. 1998). Every tree in the plots $\geq 5 \mathrm{~cm}$ diameter at 
breast height (dbh) was mapped and permanently tagged. The species and dbh (measured using a diameter tape) of each tree were recorded, as well as whether it was in the forest canopy. Canopy trees were defined as those that received direct sunlight from above and where the top of the tree was not lower than the bottom of the surrounding canopy.

Two of these plots were the site of research using increment boring to study historical canopy disturbance rates (Frelich and Graumlich 1994, Parshall 1995). Plot A is 7.2 ha and was mapped in 1987 and 1988 and then recensused in 1993 and 2006. Tree coring was done on a 5.76 ha section of the plot in the summer of 1988 by Lee Frelich and Lisa Graumlich. The $140 \times 370 \mathrm{~m}$ area was divided into a $10 \times 10 \mathrm{~m}$ grid of coring points, and the canopy tree nearest each point was cored (Fig. 1). If a coring point was not the closest coring point for any canopy trees, then no tree was cored. Trees were cored at $1.4 \mathrm{~m}$ above the ground using a $46 \mathrm{~cm}$-long Haglof increment corer with a 4.3 mm diameter core. Most trees were cored once, although a few were cored twice to attempt to get closer to the center rings of the bole. The corer was not sterilized between coring different trees, and holes left by the corer were not sealed. Plot C is 5.25 ha (150 $\times 350 \mathrm{~m}$ ) and was mapped and censused in 1990 and recensused in 1995 and 2006. Tree coring was done in the summer of 1991 by Tim Parshall and Shinya Sugita, using similar techniques to Plot A, except that the grid size was $12 \times 12 \mathrm{~m}$ and cores were taken at a height of $1.2 \mathrm{~m}$ above the ground.

For this paper we selected post-hoc control trees by creating a new set of grid points maximally distant from the coring points. Thus we located points for the control grid at $5 \mathrm{~m}$ (in Plot $\mathrm{A}$ ) or $6 \mathrm{~m}$ (in Plot $\mathrm{C}$ ) greater in the $\mathrm{x}$ - and the $\mathrm{y}$-dimension than coring points (Fig. 1). This not only maximized the distance from cored trees but also preserved the spatial pattern of sampling. We selected the nearest canopy tree to each grid point except where that tree had been cored, in which case we selected the nearest uncored canopy tree. If there were no uncored canopy trees within the $10 \times 10 \mathrm{~m}$ or $12 \times$ $12 \mathrm{~m}$ square with the control point at the center, then no control tree was selected. We used the shifted grid system rather than randomly selecting uncored canopy trees because 
the latter method would have a more clustered spatial distribution than the set of cored trees, making it an invalid control group.

For the original studies, 446 trees were cored in Plot A and 348 in Plot C. We had to remove some of the cored trees from our study to make the cored trees comparable to the control group. We used the original census determination of whether a tree was in the canopy or not for the control group. During coring the canopy status of trees was determined independently of the census data, so some trees were cored that had been categorized as not in the canopy during the original census. These trees, 77 in Plot A and 44 in Plot C, were removed from the data set so that the cored and control groups would not differ because of differences in canopy classifying methods between the censuses and the tree coring. Also, some trees from both the cored and control groups were either dead or not classified as in the canopy in the second census. Because coring took place between the first and second census, we do not know whether death or loss of canopy status occurred before the coring or not, so we removed these trees, 21 in Plot A and 7 in Plot C, from the data set. This left us a total of 348 usable cored trees in Plot A and 297 in Plot $\mathrm{C}$.

\section{Checking for Sampling Bias}

Conducting a "post-hoc" experiment must be done with care since seemingly trivial quirks in the original study could bias the results examined later. In this study a potential problem is that the original researchers could have had a bias, conscious or unconscious, towards selecting trees for coring that were not evidently rotten in the middle. Rotting or hollow trees would be unlikely to have preserved tree rings that would indicate an increase in growth caused by an opening in the canopy, and would thus not have been as useful in the original studies. At the same time, it is probable that rotting trees would have a higher mortality rate than otherwise comparable trees that do not show evidence of a decaying trunk. Thus, if trees selected for coring were less likely to be rotten, then they would be less likely to die, other things being the same, than a post-hoc control group selected without knowing whether or not the tree had evident rotting, creating a biased control sample. 
There are a number of reasons why the census data would indicate that a different tree should have been cored than the one that was selected for coring. To begin with, the locations of coring points were determined using tape measures in the field. Naturally, there would be some disagreement between where this method finds the coring point to be and where the original survey would have located it, leading to disagreement over which tree was closest to the point. Further, in Plot A trees were originally mapped using tape measures and compasses, and this was the basis for determining grid points for coring. Trees were remapped late in 1988 using Topcon surveying equipment because of errors in the original map, and it was this revised map we used to determine locations of coring grid points.

More worrisome, disparities between which trees were cored could be because an unhealthy tree was passed over for coring in favor of a healthy tree. We checked for evidence of a selection bias by comparing the mortality rate between the second and third census of "skipped" trees that should have been cored with the more distant trees that were in fact cored.

\section{Statistical Analyses}

To determine whether tree coring affected mortality we ran a nominal logistic fit with living or dead in 2006 as the response variable, and species, dbh in the first census, and whether the tree was cored or a control as predictor variables. To determine whether coring affected the growth rate of trees we ran a standard least squares fit with the 2006 $\mathrm{dbh}$ as the response variable and species, $\mathrm{dbh}$ in the first census, and whether the tree was cored or a control as predictor variables. All analyses were run in JMP 9.0.0 (2010, SAS Institute).

To look for sampling bias we used Fisher's exact test to examine whether "skipped" trees had higher mortality than their corresponding cored trees.

Annual mortality rate, $M$, was calculated as

(1) $M=1-\left(N_{t} / N_{0}\right)^{1 / t}$ 
where $N_{0}$ is the number of stems alive at time $=0, N_{t}$ is the number of stems from the original cohort that were still alive at time $t$, and $t$ is the number of years between censuses.

\section{Results}

Mortality

In Plot A 27 of 348 cored trees died between the second census (1993) and third census (2006), compared to 38 of 409 control trees. In Plot C 35 of 297 cored trees died between the second census (1995) and third census (2006), compared to 31 of 268 control trees. Coring was not a significant predictor of mortality after accounting for species and initial dbh in Plot A or Plot C (Table 2).

The annual mortality rate for cored trees in Plot A was $0.62 \%$, compared to $0.75 \%$ for control trees. In Plot $\mathrm{C}$ cored trees had an annual mortality rate of $1.13 \%$, compared to $1.11 \%$ for control trees. The annual mortality rates for all trees with equivalent census data (that is, they were in the canopy in the first and second census) were $0.68 \%$ and $1.12 \%$ for Plots A and C, respectively.

Growth

Coring was a significant predictor of $2006 \mathrm{dbh}$ in both Plot A $(\mathrm{p}=0.04)$ and Plot $\mathrm{C}(\mathrm{p}=0.01)$ in models that also included species and initial dbh as predictors (Table 2$)$. In each plot the magnitude of the effect was small, and the direction opposite of what was expected, with cored trees having annual dbh increases of 0.01 and $0.02 \mathrm{~cm}$ more than uncored trees after accounting for species and initial dbh in Plots A and C, respectively. Individual Species

No individual species in either plot showed a significant difference in mortality between cored and uncored trees, whether or not initial dbh was included in the model. The only case where the probability was less than $\mathrm{p}=0.1$ was for yellow birch in Plot A, which had a p-value of 0.07 . There was one case where there was a significant difference in dbh growth, that of sugar maple in Plot $\mathrm{C}(\mathrm{p}=0.003)$, where cored trees had a dbh increase of $0.44 \mathrm{~cm}$ greater than comparable uncored trees.

\section{Sampling Bias}


In Plot C "skipped" trees were similar in species composition and dbh to their corresponding cored trees. However, skipped trees were somewhat more likely than the subset of cored trees to have died between the second and third census (Fisher's exact test $\mathrm{p}=0.055)$. In Plot A there was no strong difference between cored and skipped trees ( $\mathrm{p}$ $=0.65)$. The species distributions of cored and skipped trees were similar, but the average dbh of the cored trees was $39.9 \mathrm{~cm}$, while for uncored trees it was $33.4 \mathrm{~cm}$.

\section{Discussion}

Researchers must weigh the potential impacts against the information to be gained when deciding whether to core a tree. In the absence of non-anecdotal evidence, some researchers have suggested that tree coring should be limited as a precaution (e.g., Harris et al. (2009)). Our results support the notion that tree coring has a minimal impact on the growth or mortality of diverse species.

Although we found that cored trees grew significantly larger than uncored trees, even after accounting for initial dbh, the magnitude of this effect was very small, amounting to around $0.2 \mathrm{~mm}$ of extra growth each year. The fact that cored trees grew larger, contrary to our expectations, could be because trees responded to coring by directing more resources to the lower trunk. On the other hand, it could reflect some bias in how trees were selected for coring.

Our research also highlights the challenges of using research studies to examine questions beyond what was originally intended. At one of our two study plots we found evidence to suggest that there could have been a bias in selecting trees for coring that were more structurally sound. The individuals who did the coring do not recall any such deliberate bias, and records show that in Plot C 70 of the 348 total trees cored did have rot in the center (Parshall 1995). This suggests that the bias was minor, as does the fact that the growth and mortality rates of cored and control trees were very similar in each plot, and also similar to the overall rates for comparable canopy trees in each plot.

Further, mortality rates for canopy trees during the same time period in our two plots that were not the site of extensive tree coring were $1.07 \%$ for Plot B and $0.99 \%$ for Plot D, intermediate between the observed mortality rates for cored trees, further suggesting that coring did not kill trees. The three most common species of cored trees in our study, 
hemlock, sugar maple, and yellow birch, had mortality rates comparable to uncored trees in our control group and to other plots in our study and other published results (Table 3).

Our study is, to our knowledge, the most rigorous examination of the question of tree coring impacts to date. Although methodological constraints may limit the definitiveness of our results, this study can offer qualified support for the proposition that coring has minimal impact on trees. Future research explicitly designed to address this question would provide further clarity on the issue. 
Table 1. Summary table of data used in this study. The first row beside each species name, with data in Roman (upright) text, is for cored trees, while the second row, with italicized text, is for control trees. "Count" is the number of trees used in the study. "Dead" is the number of the original count that died between the second and third census. $\mathrm{C} 1 \mathrm{dbh}$ and $\mathrm{C} 3 \mathrm{dbh}$ are the average dbh for the first and third census, respectively, of trees that were alive for the entirety of the study.

\begin{tabular}{|c|c|c|c|c|c|c|c|c|}
\hline & \multicolumn{4}{|c|}{ Plot A } & \multicolumn{4}{|c|}{ Plot C } \\
\hline & Count & $\mathrm{C} 1 \mathrm{dbh}$ & $\mathrm{C} 3 \mathrm{dbh}$ & Dead & Count & $\mathrm{C} 1 \mathrm{dbh}$ & $\mathrm{C} 3 \mathrm{dbh}$ & Dead \\
\hline \multirow[t]{2}{*}{ Abies balsamea } & 5 & 16.90 & 20.50 & 4 & 7 & 19.93 & 22.90 & 4 \\
\hline & 3 & 25.50 & 29.50 & 0 & 5 & 19.10 & 21.90 & 3 \\
\hline \multirow[t]{2}{*}{ Acer rubrum } & 21 & 16.83 & 21.31 & 0 & 4 & 25.07 & 31.60 & 1 \\
\hline & 28 & 16.90 & 20.70 & 2 & 3 & 18.93 & 23.67 & 0 \\
\hline \multirow[t]{2}{*}{ Acer saccharum } & 125 & 35.22 & 41.15 & 5 & 167 & 34.24 & 39.99 & 17 \\
\hline & 152 & 34.31 & 39.85 & 11 & 170 & 29.81 & 34.65 & 20 \\
\hline \multirow{2}{*}{ Betula alleghaniensis } & 47 & 45.50 & 49.03 & 11 & 39 & 42.98 & 46.88 & 5 \\
\hline & 67 & 43.50 & 47.37 & 7 & 27 & 52.14 & 55.88 & 4 \\
\hline \multirow[t]{2}{*}{ Betula papyrifera } & 0 & - & - & - & 0 & - & - & - \\
\hline & 1 & 40.40 & 42.70 & 0 & 0 & - & - & - \\
\hline \multirow[t]{2}{*}{ Fraxinus nigra } & 9 & 48.98 & 54.28 & 1 & 2 & 41.00 & 46.00 & 1 \\
\hline & 4 & 46.23 & 52.03 & 1 & 4 & 35.23 & 38.25 & 0 \\
\hline \multirow[t]{2}{*}{ Ostrya virginiana } & 1 & 13.00 & 14.50 & 0 & 0 & - & - & - \\
\hline & 0 & - & - & - & 3 & 15.23 & 16.80 & \\
\hline \multirow[t]{2}{*}{ Pinus strobus } & 4 & 69.48 & 76.88 & 0 & 0 & - & - & - \\
\hline & 2 & 17.50 & 25.10 & 0 & 0 & - & - & - \\
\hline \multirow[t]{2}{*}{ Thuja occidentalis } & 1 & 32.70 & 34.70 & 0 & 0 & - & - & - \\
\hline & 4 & 26.55 & 25.40 & 2 & 0 & - & - & - \\
\hline \multirow[t]{2}{*}{ Tilia americana } & 43 & 52.88 & 56.95 & 3 & 10 & 39.49 & 44.10 & 1 \\
\hline & 66 & 47.48 & 50.70 & 10 & 4 & 36.08 & 43.95 & 0 \\
\hline \multirow[t]{2}{*}{ Tsuga canadensis } & 92 & 45.47 & 51.68 & 3 & 68 & 44.98 & 50.82 & 6 \\
\hline & 82 & 43.05 & 48.64 & 5 & 52 & 44.63 & 50.20 & 4 \\
\hline \multirow[t]{2}{*}{ All Trees } & 348 & 37.68 & 42.64 & 27 & 297 & 33.39 & 35.51 & 35 \\
\hline & 409 & 34.73 & 39.05 & 38 & 268 & 30.74 & 38.22 & 31 \\
\hline
\end{tabular}


Table 2. Summary of results of effect tests for regressions. Starting dbh was the dbh of a tree at the time of the first census. Species is the species of tree. Cored is whether or not the tree was cored.

$\begin{array}{lcc}\text { Plot A Mortality } & & \\ & \text { Chi-squared } & \text { Prob }>\text { Chi-squared } \\ \text { Starting dbh } & 0.45 & 0.5035 \\ \text { Species } & 30.75 & 0.0006 \\ \text { Cored } & 0.40 & 0.5296\end{array}$

Plot C Mortality

$\begin{array}{lcc} & \text { Chi-squared } & \text { Prob }>\text { Chi-squared } \\ \text { Starting dbh } & 7.30 & 0.0069 \\ \text { Species } & 21.75 & 0.0028 \\ \text { Cored } & 0.02 & 0.8958\end{array}$

Plot A dbh change

$\begin{array}{lcc} & \text { F Ratio } & \text { Prob }>\text { F } \\ \text { Starting dbh } & 0.43 & 0.5135 \\ \text { Species } & 11.68 & <.0001 \\ \text { Cored } & 4.35 & 0.0375\end{array}$

Plot C dbh change

$\begin{array}{lcc} & \text { F Ratio } & \text { Prob }>\text { F } \\ \text { Starting dbh } & 3.84 & 0.0506 \\ \text { Species } & 5.15 & <.0001 \\ \text { Cored } & 6.37 & 0.0119\end{array}$


Table 3. Annual mortality rates for cored and uncored hemlock (Tsuga canadensis), sugar maple (Acer saccharum), and yellow birch (Betula alleghaniensis), and comparison to other reported values for canopy trees in old-growth forests in Upper Michigan. All Davis plots were located in the Sylvania Wilderness Area. Woods (2000) data are from the Huron Mountains and are for all stems $>30 \mathrm{~cm} \mathrm{dbh}$ at the beginning of the study. Lorimer et al. (2001) data are from the Porcupine Mountains and are for all stems $>32 \mathrm{~cm}$ dbh. Rates were calculated from raw numbers presented in Table 3 of Lorimer et al. (2001). An estimated 15\% of the trees in the Porcupine Mountains had been cored (Frelich, pers. obs.), as described in Frelich and Lorimer (1991).

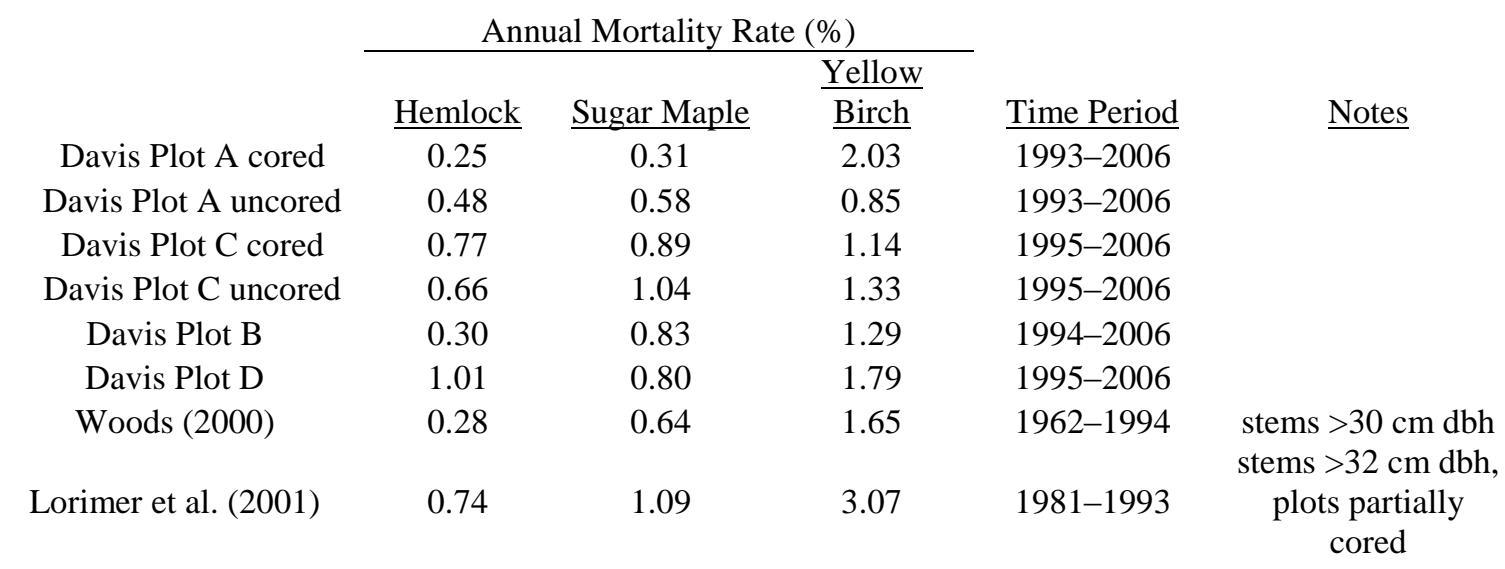


a)

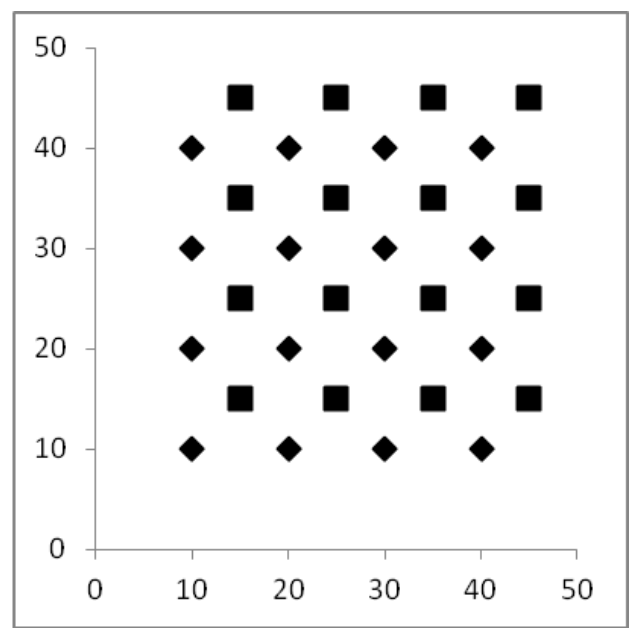

b)

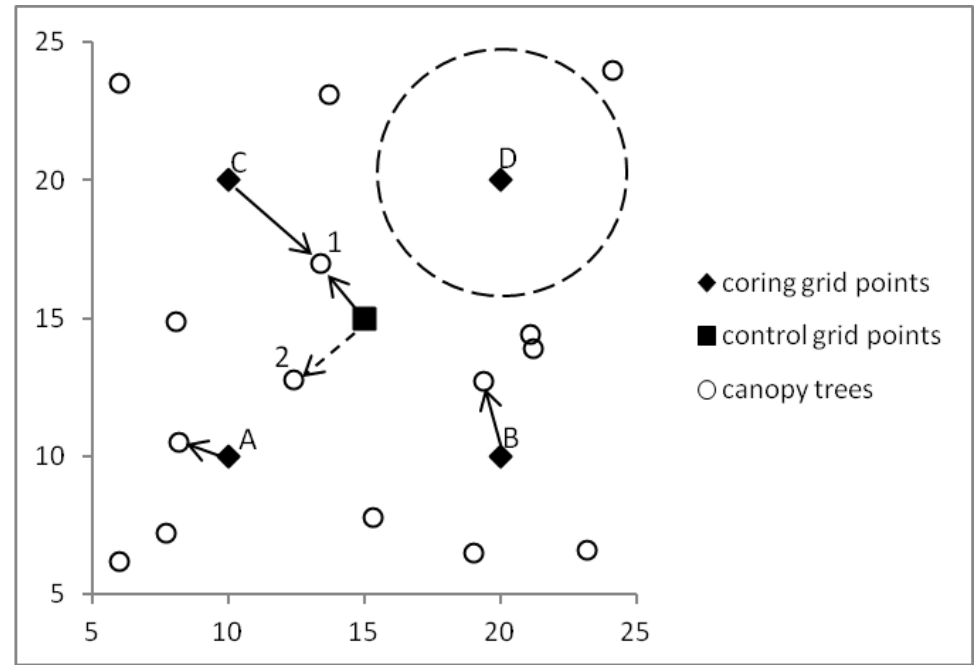

Fig. 1. Schematic diagrams of experimental layout. Fig. 1a shows how the control grid points (squares) are located to maximize the distance from coring grid points (diamonds). No grid points were located less than $10 \mathrm{~m}$ from the edge of a plot. Fig. 1b shows how study trees were selected. The nearest canopy tree to each coring grid point was cored (indicated by solid arrows). Coring grid point $\mathrm{D}$ does not have any canopy trees within a $5 \mathrm{~m}$ radius (shown by the dashed circle), so it does not have a focal tree. The nearest tree (1) to the control grid point was cored, so instead the second closest tree (2) was chosen as a focal tree. Note that in Plot C grid points are on a $12 \times 12 \mathrm{~m}$ grid instead of Plot A's $10 \times 10 \mathrm{~m}$ grid shown here 


\section{References}

Anderson, R.C., and Katz, A.J. 1993. Recovery of browse-sensitive tree species following release from white-tailed deer Odocoileus virginianus Zimmerman browsing pressure. Biological Conservation. 63: 203-208.

Anderson, R.C., and Loucks, O.L. 1979. White-tail deer (Odocoileus virginianus) influence on structure and composition of Tsuga canadensis forests. Journal of Applied Ecol. 16: 855-861.

Augustine, D.J., and Frelich, L.E. 1998. Effects of white-tailed deer on populations of an understory forb in fragmented deciduous forests. Conserv. Biol. 12: 995-1004.

Beals, E.W., Cottam, G., and Vogl, R.J. 1960. Influence of deer on vegetation of the Apostle Islands, Wisconsin. The Journal of Wildlife Management 24: 68-80.

Bockheim, J.G. and Jordan, J. 2004. Soils of the Sylvania Wilderness-Recreation Area, Western Upper Peninsula, Michigan. United States Department of Agriculture Forest Service Technical Report NC-237.

Cahill, J.F., Castelli, J.P., and Casper, B.B. 2001. The herbivory uncertainty principle: visiting plants can alter herbivory. Ecology 82: 307-312.

Comita, L.S., and Goldsmith, G.R. 2008. Impact of research trails on seedling dynamics in a tropical forest. Biotropica 40: 251-254.

Comita, L.S., Goldsmith, G.R., and Hubbell, S.P. 2009. Intensive research activity alters short-term seedling dynamics in a tropical forest. Ecological Research 24: 225-230.

Dahlberg, B.L., and Guettinger, R.C. 1956. The white-tailed deer in Wisconsin. Wisconsin Dept. of Natural Resources Technical Bulletin 14. 
Davis, M.B., Parshall, T.E., and Ferrari, J.B. 1996. Landscape heterogeneity of hemlockhardwood forest in northern Michigan. In Eastern old-growth forests: Prospects for rediscovery and recovery. Island Press, Washington, D.C., USA, pp. 291-304.

Davis, M.B., Calcote, R.R., Sugita, S., and Takahara, H. 1998. Patchy invasion and the origin of a hemlock-hardwoods forest mosaic. Ecology 79: 2641-2659.

Davis, M.B., Sugita, S., Calcote, R.R., Ferrari, J.B., and Frelich, L. 1994. Historical development of alternate communities in a hemlock-hardwood forest in northern Michigan, USA. In Large-scale ecology and conservation biology. Blackwell Scientific Publications, Oxford, UK, pp. 19-39.

Davis, M.D. 1996. Extent and location. In Eastern old-growth forests: prospects for rediscovery and recovery. Island Press, Washington, D.C., USA, pp. 18-32.

Doepker, R.V., Beyer, D.E., and Donovan, M. 1995. Deer population trends in Michigan's Upper Peninsula. Michigan Department of Natural Resources, Wildlife Division Report 3254.

Frelich, L.E. 2002. Forest dynamics and disturbance regimes: Studies from temperate evergreen-deciduous forests. Cambridge Univ. Press, Cambridge, UK.

Frelich, L.E. 1995. Old forest in the Lake States today and before European settlement. Nat. Areas J. 15: 157-167.

Frelich, L.E., and Reich, P.B. 2010. Will environmental changes reinforce the impact of global warming on the prairie-forest border of central North America? Frontiers in Ecology and the Environment 8: 371-378.

Frelich, L.E., and Reich, P.B. 2009. Wilderness conservation in an era of global warming and invasive species: A case study from Minnesota's Boundary Waters Canoe Area Wilderness. Nat. Areas J. 29: 385-393. 
Frelich, L.E., and Graumlich, L.J. 1994. Age-class distribution and spatial patterns in an old-growth hemlock-hardwood forest. Canadian journal of forest research 24:19391947.

Frelich, L.E., and Lorimer, C.G. 1991. A simulation of landscape-level stand dynamics in the northern hardwood region. The Journal of Ecology 79: 223-233.

Frelich, L.E., and Lorimer, C.G. 1985. Current and predicted long-term effects of deer browsing in hemlock forests in Michigan, USA. Biol. Conserv. 34: 99-120.

Frelich, L.E., Calcote, R.R., Davis, M.B., and Pastor, J. 1993. Patch formation and maintenance in an old-growth hemlock-hardwood forest. Ecology 74: 513-527.

Frelich, L.E., Hale, C.M., Scheu, S., Holdsworth, A.R., Heneghan, L., Bohlen, P.J., and Reich, P.B. 2006. Earthworm invasion into previously earthworm-free temperate and boreal forests. Biol. Invasions 8: 1235-1245.

Fuller, R. J., and Gill, R.M.A. 2002. Ecological impacts of increasing numbers of deer in British woodland. Forestry 74:193-199.

Gadotti, C., and Batalha, M. 2010. The 'Herbivory Uncertainty Principle': Application in a cerrado site. Brazilian Journal of Biology 70: 279-282.

Godman, R.M., Yawney, H.W., and Tubbs, C.H. 1990. Acer saccharum Marsh. In Silvics of North America. Volume 2, Hardwoods. US Department of Agriculture Handbook 645:78-91.

Graham, S.A. 1954. Changes in northern Michigan forests from browsing by deer. Trans. North Am. Wildl. Conf. 19: pp. 526-533.

Hale, C.M., Frelich, L.E., Reich, P.B., and Pastor, J. 2005. Effects of European earthworm invasion on soil characteristics in northern hardwood forests of Minnesota, USA. Ecosystems 8: 911-927. 
Harris, S., Allen, K., Baker, P., Bird, T., Bowman, D., Connolly, A., d'Arville, L., Harwood, C., Rozefelds, A., and Wardlaw, T. 2009. Guidelines for collecting and conserving dendrochronology samples from Tasmanian public reserves. Tasforests 18: $145-152$.

Henne, P.D., Hu, F.S., and Cleland, D.T. 2007. Lake-effect snow as the dominant control of mesic-forest distribution in Michigan, USA. Ecology 95: 517-529.

Hepting, G.H., Roth, E.R., and Sleeth, B. 1949. Discolorations and decay from increment borings. Journal of Forestry 47: 366-370.

Holdsworth, A.R., Frelich, L., and Reich, P.B. 2007. Effects of earthworm invasion on plant species richness in northern hardwood forests. Conserv. Biol. 21: 997-1008.

Horsley, S. B., Stout, S. L., and DeCalesta, D. S. 2003. White-tailed deer impact on the vegetation dynamics of a northern hardwood forest. Ecol. App. 13:98-118.

Husheer, S. W., Coomes, D. A., and Robertson, A. W. 2003. Long-term influences of introduced deer on the composition and structure of New Zealand Nothofagus forests. For. Ecol. and Management 181:99-117.

Kuijper, D. P. J., Jędrzejewska, B., Brzezicki, B., Churski, M., Jędrzejewski, W., and Żybura, H. 2010. Fluctuating ungulate density shapes tree recruitment in natural stands of the Białowieża Primeval Forest, Poland. J. of Veg. Science 21:1082-1098.

Laflamme, G. 1979. Discoloured wood of aspen caused by increment boring. European Journal of Forest Pathology 9: 15-18.

Leopold, A. 1943. Deer irruptions. Wisconsin Conservation Bulletin 8: 3-11.

Lorenz, R.C. 1944. Discolorations and decay resulting from increment borings in hardwoods. Journal of Forestry 42: 37-43. 
Marx, L., and Walters, M.B. 2008. Survival of tree seedlings on different species of decaying wood maintains tree distribution in Michigan hemlock-hardwood forests. J. Ecol. 96: 505-513.

Mladenoff, D.J., White, M.A., Pastor, J., and T.R. Crow. 1993. Comparing spatial pattern in unaltered old-growth and disturbed forest landscapes. Ecol. Applications 3: 294-306.

Mudrak, E.L., Johnson, S.E., and Waller, D.M. 2009. Forty-seven year changes in vegetation at the Apostle Islands: Effects of deer on the forest understory. Nat. Areas J. 29: $167-176$.

Niinemets, Ü., and Valladares, F. 2006. Tolerance to shade, drought, and waterlogging of temperate Northern Hemisphere trees and shrubs. Ecol. Monographs 76:521-547.

Parshall, T.E. 1993. Canopy disturbances mediate species composition changes in a northern hemlock-hardwood forest mosaic. Master's Thesis, University of Minnesota, Twin Cities.

Parshall, T. 1995. Canopy mortality and stand-scale change in a northern hemlockhardwood forest. Canadian Journal of Forest Research 25: 1466-1478.

Pastor, J., and Broschart, M. 1990. The spatial pattern of a northern conifer-hardwood landscape. Landscape Ecol. 4: 55-68.

Prasad, A. M., Iverson, L.R., Matthews. S., Peters, M. 2007-ongoing. A Climate Change Atlas for 134 Forest Tree Species of the Eastern United States [database]. http://www.nrs.fs.fed.us/atlas/tree, Northern Research Station, USDA Forest Service, Delaware, Ohio.

PRISM Climate Group. 2010. http://www.prism.oregonstate.edu/. Accessed 25 October 2010. 
Rooney, T.P., and Waller, D.M. 1998. Local and regional variation in hemlock seedling establishment in forests of the upper Great Lakes region, USA. For. Ecol. and Management 111: 211-224.

Rooney, T.P., McCormick, R.J., Sodheim, S.L., and Waller, D.M. 2000. Regional variation in recruitment of hemlock seedlings and saplings in the upper Great Lakes, USA. Ecol. Applications 10:1119-1132.

Schnitzer, S.A., Reich, P.B., Bergner, B., and Carson, W.P. 2002. Herbivore and pathogen damage on grassland and woodland plants: a test of the herbivore uncertainty principle. Ecology Letters 5: 531-539.

Tremblay, J.P., Thibault, I., Dussault, C., Huot, J., and Côté, S.D. 2005. Long-term decline in white-tailed deer browse supply: Can lichens and litterfall act as alternative food sources that preclude density-dependent feedbacks. Can. J. Zool. 83: 1087-1096.

Walker, K.V., Davis, M.B., and Sugita, S. 2002. Climate change and shifts in potential tree species range limits in the Great Lakes region. J. Great Lakes Res. 28: 555-567.

Witt, J. C., and C. R. Webster. 2010. Regeneration dynamics in remnant Tsuga canadensis stands in the northern Lake States: Potential direct and indirect effects of herbivory. For. Ecol. and Management 260: 519-525.

Wuebbles, D.J., and Hayhoe, K. 2004. Climate change projections for the United States Midwest. Mitigation Adapt. Strat. Global Change 9: 335-363. 


\section{Appendix A}

\section{Census 1}

\begin{tabular}{|c|c|c|c|c|c|c|c|c|c|c|c|c|c|}
\hline & & & $15-$ & $25-$ & $35-$ & $45-$ & $55-$ & $65-$ & $75-$ & $85-$ & 95- & $105-$ & $115-$ \\
\hline Plot & SPECIES & $5-15$ & 25 & 35 & 45 & 55 & 65 & 75 & 85 & 95 & 105 & 115 & 125 \\
\hline A & Fraxinus nigra & 0.97 & 2.36 & 0.97 & 0.28 & 1.94 & 0.28 & 0.28 & 0 & 0 & 0 & 0 & 0 \\
\hline A & Picea mariana & 2.08 & 0.97 & 0.14 & 0 & 0 & 0 & 0 & 0 & 0 & 0 & 0 & 0 \\
\hline A & Thuja occidentalis & 0.14 & 3.61 & 5.00 & 1.25 & 0.28 & 0 & 0 & 0 & 0 & 0 & 0 & 0 \\
\hline A & Ulmus americana & 0.14 & 0 & 0 & 0 & 0 & 0 & 0 & 0 & 0 & 0 & 0 & 0 \\
\hline A & Abies balsamea & 11.11 & 5.14 & 1.11 & 0 & 0 & 0 & 0 & 0 & 0 & 0 & 0 & 0 \\
\hline A & Tsuga canadensis & 26.25 & 31.81 & 24.03 & 17.50 & 15.00 & 8.61 & 3.75 & 0.28 & 0 & 0 & 0 & 0 \\
\hline A & Ostrya virginiana & 18.19 & 1.39 & 0.14 & 0 & 0 & 0 & 0 & 0 & 0 & 0 & 0 & 0 \\
\hline A & Betula papyrifera & 0 & 0 & 0 & 0.14 & 0 & 0 & 0.14 & 0 & 0 & 0 & 0 & 0 \\
\hline A & Acer rubrum & 47.22 & 8.47 & 1.25 & 0.42 & 0.14 & 0.28 & 0 & 0 & 0 & 0 & 0 & 0 \\
\hline A & Acer saccharum & 182.36 & 40.69 & 20.97 & 13.47 & 11.11 & 5.97 & 3.19 & 0.69 & 0 & 0 & 0 & 0 \\
\hline A & Tilia americana & 1.81 & 1.53 & 5.14 & 11.11 & 11.25 & 8.06 & 2.64 & 0.42 & 0.28 & 0 & 0 & 0 \\
\hline A & Pinus strobus & 1.53 & 1.39 & 0.56 & 0.42 & 0.14 & 0.28 & 0.14 & 0 & 0.42 & 0 & 0 & 0.14 \\
\hline A & $\begin{array}{l}\text { Picea glauca } \\
\text { Betula }\end{array}$ & 0.56 & 0 & 0 & 0 & 0 & 0 & 0 & 0 & 0 & 0 & 0 & 0 \\
\hline A & allegheniensis & 6.39 & 10.56 & 10.83 & 9.72 & 9.03 & 6.81 & 2.92 & 1.53 & 0.42 & 0 & 0 & 0 \\
\hline B & $\begin{array}{l}\text { Alnus rugosa } \\
\text { Amelanchier }\end{array}$ & 0.30 & 0 & 0 & 0 & 0 & 0 & 0 & 0 & 0 & 0 & 0 & 0 \\
\hline B & canadensis & 0.10 & 0 & 0 & 0 & 0 & 0 & 0 & 0 & 0 & 0 & 0 & 0 \\
\hline B & $\begin{array}{l}\text { Fraxinus nigra } \\
\text { Carpinus }\end{array}$ & 1.30 & 5.30 & 12.30 & 4.60 & 1.20 & 0.50 & 0 & 0 & 0 & 0.10 & 0 & 0 \\
\hline B & caroliniana & 0.10 & 0 & 0 & 0 & 0 & 0 & 0 & 0 & 0 & 0 & 0 & 0 \\
\hline B & Picea mariana & 3.90 & 0.60 & 0 & 0 & 0 & 0 & 0 & 0 & 0 & 0 & 0 & 0 \\
\hline B & Thuja occidentalis & 2.40 & 4.10 & 3.40 & 1.20 & 0.20 & 0 & 0 & 0 & 0 & 0 & 0 & 0 \\
\hline B & Ulmus americana & 0.60 & 0.10 & 0 & 0 & 0 & 0 & 0 & 0 & 0 & 0 & 0 & 0 \\
\hline B & $\begin{array}{l}\text { Abies balsamea } \\
\text { Fraxinus }\end{array}$ & 14.50 & 7.50 & 1.80 & 0.20 & 0 & 0 & 0 & 0 & 0 & 0 & 0 & 0 \\
\hline B & pennsylvanica & 0.10 & 0 & 0 & 0 & 0 & 0 & 0 & 0 & 0 & 0 & 0 & 0 \\
\hline B & Tsuga canadensis & 14.20 & 29.60 & 26.90 & 20.00 & 14.70 & 9.20 & 4.20 & 2.40 & 0.40 & 0.10 & 0 & 0 \\
\hline
\end{tabular}




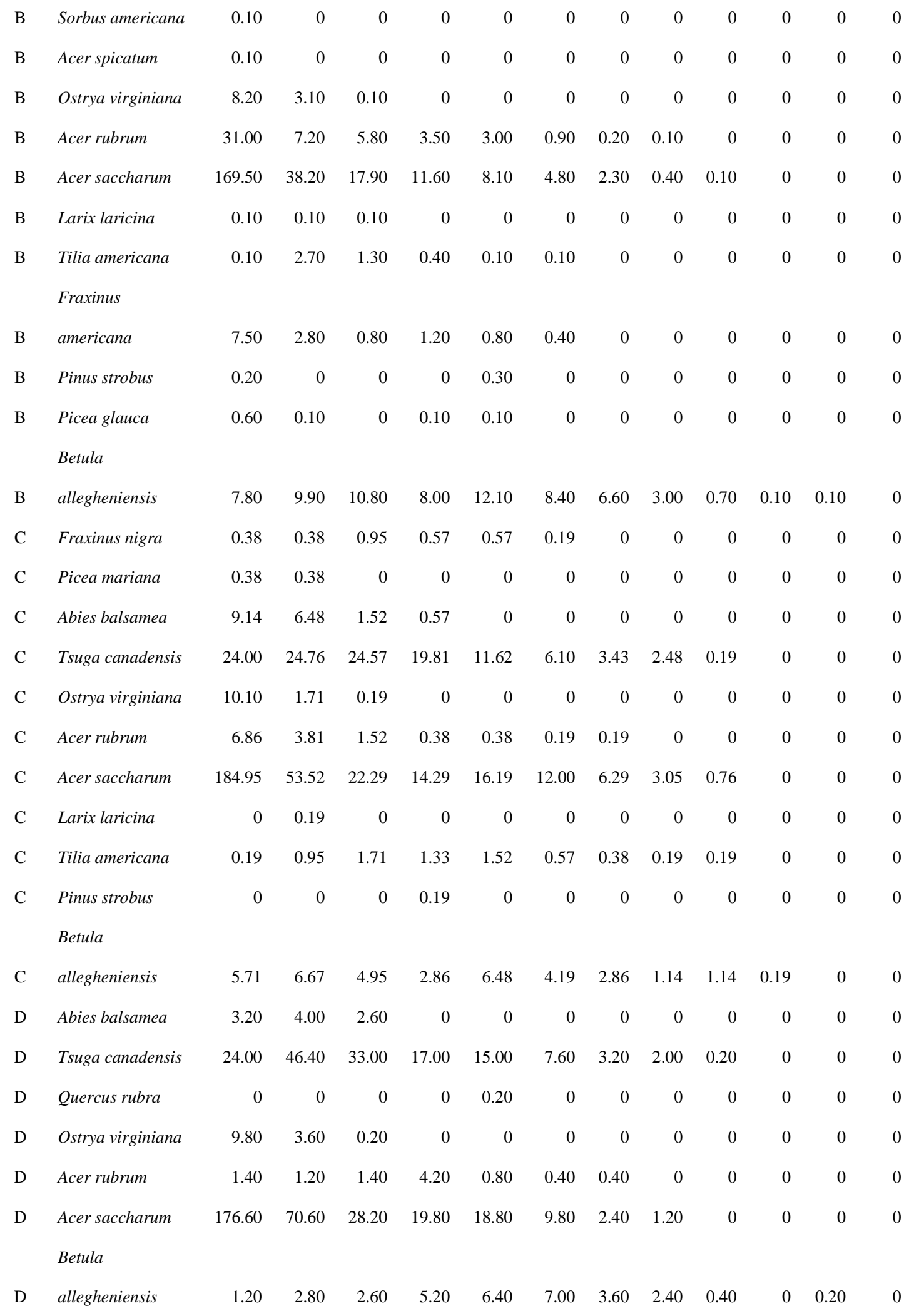




\section{Census 2}

\begin{tabular}{|c|c|c|c|c|c|c|c|c|c|c|c|c|c|}
\hline & & & $15-$ & $25-$ & $35-$ & $45-$ & $55-$ & $65-$ & $75-$ & $85-$ & 95- & $105-$ & $115-$ \\
\hline Plot & SPECIES & $5-15$ & 25 & 35 & 45 & 55 & 65 & 75 & 85 & 95 & 105 & 115 & 125 \\
\hline A & Fraxinus nigra & 0.42 & 2.64 & 0.97 & 0.14 & 1.81 & 0.14 & 0.28 & 0 & 0 & 0 & 0 & 0 \\
\hline A & Picea mariana & 1.39 & 0.97 & 0.14 & 0 & 0 & 0 & 0 & 0 & 0 & 0 & 0 & 0 \\
\hline A & Thuja occidentalis & 0.14 & 2.36 & 4.86 & 1.53 & 0.28 & 0 & 0 & 0 & 0 & 0 & 0 & 0 \\
\hline A & Ulmus americana & 0.14 & 0 & 0 & 0 & 0 & 0 & 0 & 0 & 0 & 0 & 0 & 0 \\
\hline A & Abies balsamea & 7.22 & 4.31 & 1.25 & 0 & 0 & 0 & 0 & 0 & 0 & 0 & 0 & 0 \\
\hline A & Tsuga canadensis & 22.08 & 29.58 & 23.75 & 18.47 & 14.44 & 9.03 & 5.14 & 0.42 & 0 & 0 & 0 & 0 \\
\hline A & Ostrya virginiana & 19.03 & 2.36 & 0.14 & 0 & 0 & 0 & 0 & 0 & 0 & 0 & 0 & 0 \\
\hline A & Betula papyrifera & 0 & 0 & 0 & 0.14 & 0 & 0 & 0 & 0 & 0 & 0 & 0 & 0 \\
\hline A & Acer rubrum & 41.67 & 11.39 & 0.97 & 0.42 & 0.28 & 0.28 & 0 & 0 & 0 & 0 & 0 & 0 \\
\hline A & Acer saccharum & 180.28 & 44.58 & 22.22 & 13.75 & 11.11 & 6.53 & 2.78 & 0.83 & 0 & 0 & 0 & 0 \\
\hline A & Tilia americana & 1.94 & 1.39 & 3.89 & 11.25 & 9.72 & 8.06 & 2.92 & 0.97 & 0.28 & 0 & 0 & 0 \\
\hline A & Pinus strobus & 0.97 & 1.39 & 0.83 & 0.42 & 0.14 & 0 & 0.28 & 0.14 & 0.28 & 0 & 0 & 0.14 \\
\hline A & $\begin{array}{l}\text { Picea glauca } \\
\text { Betula }\end{array}$ & 0.56 & 0 & 0 & 0 & 0 & 0 & 0 & 0 & 0 & 0 & 0 & 0 \\
\hline A & allegheniensis & 5.28 & 8.19 & 11.25 & 8.75 & 8.06 & 6.53 & 3.06 & 1.11 & 0.28 & 0.14 & 0 & 0 \\
\hline B & $\begin{array}{l}\text { Alnus rugosa } \\
\text { Amelanchier }\end{array}$ & 0.30 & 0 & 0 & 0 & 0 & 0 & 0 & 0 & 0 & 0 & 0 & 0 \\
\hline B & canadensis & 0.10 & 0 & 0 & 0 & 0 & 0 & 0 & 0 & 0 & 0 & 0 & 0 \\
\hline B & $\begin{array}{l}\text { Fraxinus nigra } \\
\text { Carpinus }\end{array}$ & 1.30 & 4.00 & 10.90 & 6.00 & 1.20 & 0.40 & 0 & 0 & 0 & 0 & 0 & 0 \\
\hline B & caroliniana & 0.20 & 0 & 0 & 0 & 0 & 0 & 0 & 0 & 0 & 0 & 0 & 0 \\
\hline B & Picea mariana & 3.40 & 0.60 & 0 & 0 & 0 & 0 & 0 & 0 & 0 & 0 & 0 & 0 \\
\hline B & Thuja occidentalis & 2.30 & 3.50 & 3.30 & 1.20 & 0.30 & 0 & 0 & 0 & 0 & 0 & 0 & 0 \\
\hline B & Ulmus americana & 0.70 & 0.10 & 0 & 0 & 0 & 0 & 0 & 0 & 0 & 0 & 0 & 0 \\
\hline B & $\begin{array}{l}\text { Abies balsamea } \\
\text { Fraxinus }\end{array}$ & 11.60 & 6.20 & 1.20 & 0.30 & 0 & 0 & 0 & 0 & 0 & 0 & 0 & 0 \\
\hline B & pennsylvanica & 0.10 & 0 & 0 & 0 & 0 & 0 & 0 & 0 & 0 & 0 & 0 & 0 \\
\hline B & Tsuga canadensis & 10.60 & 29.30 & 27.50 & 19.70 & 14.60 & 10.50 & 5.00 & 2.60 & 0.80 & 0.10 & 0 & 0 \\
\hline
\end{tabular}




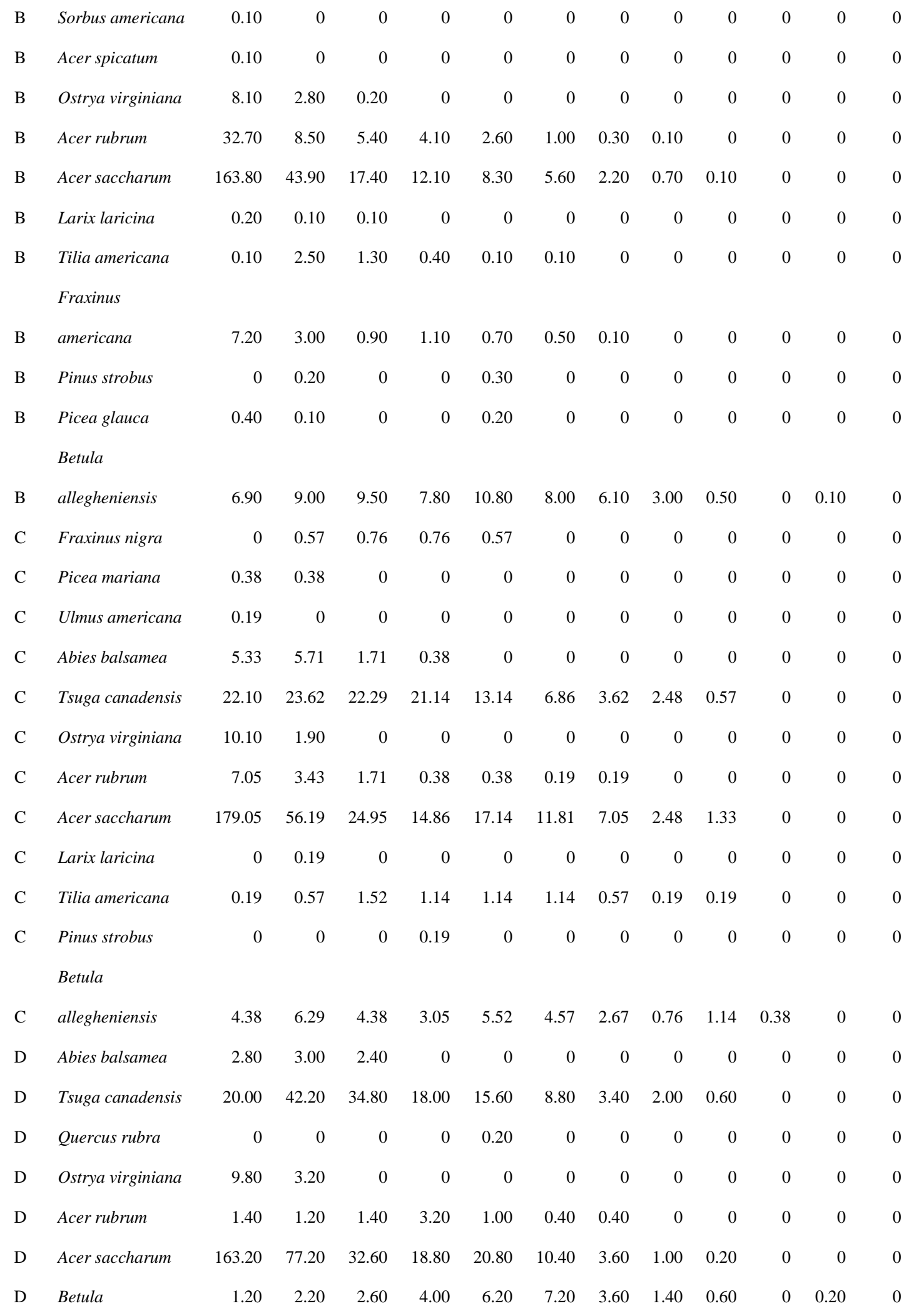


allegheniensis

\section{Census 3}

\begin{tabular}{|c|c|c|c|c|c|c|c|c|c|c|c|c|c|}
\hline & & & $15-$ & $25-$ & $35-$ & $45-$ & $55-$ & $65-$ & $75-$ & $85-$ & $95-$ & $105-$ & $115-$ \\
\hline Plot & SPECIES & $5-15$ & 25 & 35 & 45 & 55 & 65 & 75 & 85 & 95 & 105 & 115 & 125 \\
\hline A & Fraxinus nigra & 0.14 & 2.08 & 0.97 & 0.28 & 0.83 & 0.97 & 0.14 & 0.14 & 0 & 0 & 0 & 0 \\
\hline $\mathrm{A}$ & Prunus serotina & 0.14 & 0 & 0 & 0 & 0 & 0 & 0 & 0 & 0 & 0 & 0 & 0 \\
\hline A & Picea mariana & 0.14 & 1.39 & 0 & 0 & 0 & 0 & 0 & 0 & 0 & 0 & 0 & 0 \\
\hline A & Thuja occidentalis & 0.14 & 1.94 & 3.89 & 1.67 & 0.42 & 0 & 0 & 0 & 0 & 0 & 0 & 0 \\
\hline A & Ulmus americana & 0 & 0.14 & 0 & 0 & 0 & 0 & 0 & 0 & 0 & 0 & 0 & 0 \\
\hline A & Abies balsamea & 4.17 & 2.78 & 0.69 & 0 & 0 & 0 & 0 & 0 & 0 & 0 & 0 & 0 \\
\hline A & Tsuga canadensis & 15.28 & 26.67 & 22.64 & 18.89 & 14.03 & 12.08 & 5.56 & 1.39 & 0 & 0.14 & 0 & 0 \\
\hline A & Ostrya virginiana & 21.67 & 2.08 & 0 & 0 & 0 & 0 & 0 & 0 & 0 & 0 & 0 & 0 \\
\hline A & Betula papyrifera & 0 & 0 & 0 & 0.14 & 0 & 0 & 0 & 0 & 0 & 0 & 0 & 0 \\
\hline A & Acer rubrum & 30.56 & 14.03 & 1.53 & 0.42 & 0.56 & 0 & 0.28 & 0 & 0 & 0 & 0 & 0 \\
\hline A & Acer saccharum & 161.81 & 47.92 & 25.69 & 16.25 & 11.11 & 7.08 & 4.44 & 1.25 & 0 & 0 & 0 & 0 \\
\hline A & Tilia americana & 1.53 & 1.11 & 2.78 & 8.75 & 8.06 & 8.47 & 3.19 & 1.25 & 0 & 0.14 & 0 & 0 \\
\hline A & Pinus strobus & 0.69 & 1.11 & 0.83 & 0.28 & 0.28 & 0.14 & 0.14 & 0.28 & 0.14 & 0.14 & 0 & 0.14 \\
\hline A & $\begin{array}{l}\text { Picea glauca } \\
\text { Betula }\end{array}$ & 0.28 & 0.14 & 0 & 0 & 0 & 0 & 0 & 0 & 0 & 0 & 0 & 0 \\
\hline A & allegheniensis & 3.33 & 5.56 & 9.44 & 7.92 & 7.22 & 5.42 & 2.64 & 1.11 & 0.28 & 0.14 & 0 & 0 \\
\hline B & $\begin{array}{l}\text { Alnus rugosa } \\
\text { Amelanchier }\end{array}$ & 0.10 & 0 & 0 & 0 & 0 & 0 & 0 & 0 & 0 & 0 & 0 & 0 \\
\hline B & canadensis & 0.10 & 0 & 0 & 0 & 0 & 0 & 0 & 0 & 0 & 0 & 0 & 0 \\
\hline B & $\begin{array}{l}\text { Fraxinus nigra } \\
\text { Carpinus }\end{array}$ & 1.10 & 1.70 & 6.10 & 6.30 & 1.50 & 0.40 & 0.10 & 0 & 0 & 0 & 0 & 0 \\
\hline B & caroliniana & 0.30 & 0 & 0 & 0 & 0 & 0 & 0 & 0 & 0 & 0 & 0 & 0 \\
\hline B & Picea mariana & 2.50 & 0.70 & 0 & 0 & 0 & 0 & 0 & 0 & 0 & 0 & 0 & 0 \\
\hline B & Thuja occidentalis & 1.90 & 3.30 & 2.50 & 1.10 & 0.60 & 0 & 0 & 0 & 0 & 0 & 0 & 0 \\
\hline B & Ulmus americana & 0.80 & 0.20 & 0.10 & 0 & 0 & 0 & 0 & 0 & 0 & 0 & 0 & 0 \\
\hline B & Abies balsamea & 6.10 & 3.00 & 0.30 & 0.10 & 0 & 0 & 0 & 0 & 0 & 0 & 0 & 0 \\
\hline
\end{tabular}


Fraxinus

\begin{tabular}{|c|c|c|c|c|c|c|c|c|c|c|c|c|}
\hline B & pennsylvanica & 1.50 & 0 & 0 & 0 & 0 & 0 & 0 & 0 & 0 & 0 & \multirow[b]{2}{*}{0.10} \\
\hline B & Tsuga canadensis & 8.40 & 22.60 & 24.30 & 21.00 & 16.10 & 11.50 & 6.30 & 3.00 & 1.20 & 0.20 & \\
\hline B & Sorbus americana & 0.10 & 0 & 0 & 0 & 0 & 0 & 0 & 0 & 0 & 0 & 0 \\
\hline B & Acer spicatum & 0.10 & 0 & 0 & 0 & 0 & 0 & 0 & 0 & 0 & 0 & 0 \\
\hline B & Ostrya virginiana & 9.10 & 2.90 & 0.20 & 0 & 0 & 0 & 0 & 0 & 0 & 0 & 0 \\
\hline B & Acer rubrum & 29.30 & 8.50 & 6.00 & 4.70 & 2.40 & 1.20 & 0.10 & 0.10 & 0 & 0 & 0 \\
\hline B & Acer saccharum & 131.00 & 51.90 & 19.20 & 11.60 & 9.40 & 4.60 & 2.90 & 0.80 & 0.10 & 0 & 0 \\
\hline B & Larix laricina & 1.10 & 0 & 0.20 & 0 & 0 & 0 & 0 & 0 & 0 & 0 & 0 \\
\hline B & Tilia americana & 0.10 & 0.60 & 2.20 & 0.40 & 0.30 & 0.10 & 0 & 0 & 0 & 0 & 0 \\
\hline & Fraxinus & & & & & & & & & & & \\
\hline B & americana & 6.70 & 2.80 & 1.40 & 0.40 & 0.70 & 0.20 & 0.30 & 0 & 0 & 0 & 0 \\
\hline B & Pinus strobus & 0 & 0.10 & 0.10 & 0 & 0.30 & 0 & 0 & 0 & 0 & 0 & 0 \\
\hline B & Picea glauca & 0.50 & 0.20 & 0 & 0 & 0.20 & 0 & 0 & 0 & 0 & 0 & 0 \\
\hline & Betula & & & & & & & & & & & \\
\hline B & allegheniensis & 7.40 & 7.60 & 7.90 & 7.50 & 8.70 & 6.50 & 5.60 & 3.00 & 0.60 & 0.10 & 0 \\
\hline $\mathrm{C}$ & Fraxinus nigra & 0 & 0.57 & 0.57 & 0.38 & 0.76 & 0.19 & 0 & 0 & 0 & 0 & 0 \\
\hline $\mathrm{C}$ & Picea mariana & 0.19 & 0.38 & 0.19 & 0 & 0 & 0 & 0 & 0 & 0 & 0 & 0 \\
\hline $\mathrm{C}$ & Abies balsamea & 1.90 & 2.48 & 0.76 & 0 & 0 & 0 & 0 & 0 & 0 & 0 & 0 \\
\hline $\mathrm{C}$ & Tsuga canadensis & 17.14 & 18.86 & 21.14 & 20.19 & 13.52 & 6.86 & 5.33 & 2.86 & 0.57 & 0.19 & 0 \\
\hline $\mathrm{C}$ & Ostrya virginiana & 9.33 & 1.33 & 0.19 & 0 & 0 & 0 & 0 & 0 & 0 & 0 & 0 \\
\hline $\mathrm{C}$ & Acer rubrum & 5.52 & 3.81 & 2.29 & 0.57 & 0.19 & 0.38 & 0 & 0.19 & 0 & 0 & 0 \\
\hline $\mathrm{C}$ & Acer saccharum & 174.10 & 57.14 & 28.76 & 15.43 & 13.52 & 11.62 & 6.29 & 2.86 & 0.95 & 0 & 0 \\
\hline $\mathrm{C}$ & Larix laricina & 0 & 0 & 0.19 & 0 & 0 & 0 & 0 & 0 & 0 & 0 & 0 \\
\hline $\mathrm{C}$ & Tilia americana & 0 & 0.57 & 1.14 & 0.76 & 1.14 & 0.95 & 0.76 & 0 & 0.19 & 0.19 & 0 \\
\hline $\mathrm{C}$ & Pinus strobus & 0 & 0 & 0 & 0 & 0.19 & 0 & 0 & 0 & 0 & 0 & 0 \\
\hline & Betula & & & & & & & & & & & \\
\hline $\mathrm{C}$ & allegheniensis & 2.48 & 4.95 & 4.19 & 3.43 & 3.81 & 3.81 & 2.29 & 0.95 & 0.76 & 0 & 0 \\
\hline $\mathrm{D}$ & Abies balsamea & 1.40 & 1.60 & 1.00 & 0 & 0 & 0 & 0 & 0 & 0 & 0 & 0 \\
\hline $\mathrm{D}$ & Tsuga canadensis & 13.20 & 33.40 & 33.60 & 18.20 & 13.00 & 9.00 & 5.60 & 1.80 & 0.60 & 0 & 0 \\
\hline $\mathrm{D}$ & Ostrya virginiana & 8.20 & 3.20 & 0 & 0 & 0 & 0 & 0 & 0 & 0 & 0 & 0 \\
\hline $\mathrm{D}$ & Acer rubrum & 0.40 & 0.60 & 1.40 & 1.60 & 2.80 & 0.20 & 0.60 & 0.20 & 0 & 0 & 0 \\
\hline D & Acer saccharum & 120.00 & 73.00 & 36.40 & 24.00 & 18.60 & 12.00 & 5.00 & 1.40 & 0 & 0 & 0 \\
\hline
\end{tabular}




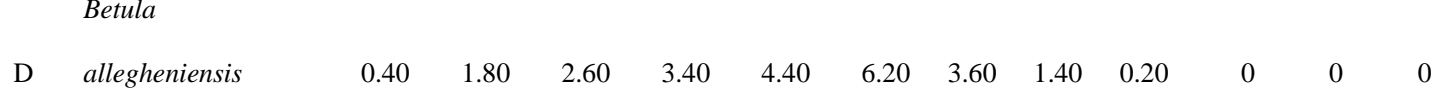

